\title{
RAZUMIJEVANJE ŽIVOTNOG CIKLUSA I OPLODNJE TIJEKOM UČENJA BIOLOGIJE U OSNOVNOJ ŠKOLI
}

\author{
Monika Golubić ${ }^{1}$, Valerija Begić 2 , Žaklin Lukšă ${ }^{3}$, Petra Korać ${ }^{4}$, Ines Radanović \\ ${ }^{1}$ Osnovna škola Sunja, Ljudevita Posavskog 55 a, 44210 Sunja \\ golubicmonika@gmail.com \\ 2 Osnovna škola Sesvetski Kraljevec, Školska 10, 10000 Zagreb \\ ${ }^{3}$ Gimnazija Josipa Slavenskog Čakovec, V, Nazora 34, 40000 Čakovec \\ ${ }^{4}$ Biološki odsjek Prirodoslovno matematičkog fakulteta Sveučilišta u Zagrebu, Rooseveltov trg 6, 10000 Zagreb
}

\section{SAŽETAK}

Cilj ovog istraživanja je odrediti usvojenost $\mathrm{i}$ konceptualno razumijevanje makrokoncepta Razmnožavanje $\mathrm{i}$ razvoj organizma među učenicima 7. i 8. razreda osnovnih škola, na temelju učeničkih odgovora na pitanja uz makrokoncept Razmnožavanje i razvoj organizma na Županijskom natjecanju iz biologije 2015. i 2017. godine. Analiza učeničkih odgovora uključivala je specifično kodiranje odgovora i tumačenje biološkog značenja odgovora učenika. Izdvojeni su i objašnjeni problemi koje učenici pokazuju u svojim odgovorima kao i njihove miskoncepcije vezane uz koncept razmnožavanje. Utvrđeno je i opisano postojanje niza problema kod usvojenosti koncepta razmnožavanje te su kao najizraženije uočene miskoncepcije uz ključni koncept životni ciklus stanice i organizma te kod razumijevanja koncepta oplodnje. Utvrđene miskoncepcije ukazuju na nužnu promjenu organizacije nastavnih sadržaja biologije, kao i na potrebu uvođenja novih nastavnih strategija $s$ naglaskom na aktivnost i samostalni rad učenika.

Ključne riječi: konceptualno razumijevanje, makrokoncept Razmnožavanje i razvoj organizma, 7. i 8. razred osnovne škole, natjecanje učenika, problemi i miskoncepcije

\section{UVOD}

Da bi se u nastavi kod učenika uspješno utvrdila i otklonila prisutnost odstupanja od znanstvenih koncepata, u nastavi se sve više teži koristiti aktivne metode učenja umjesto tradicionalnog, predavačkog oblika nastave. Prema Tanner i Allenu (2005), poučavanje se treba prilagoditi učenicima, odnosno onome što oni "znaju" - njihovim predkoncepcijama i miskoncepcijama, koje se tijekom formalnog obrazovanja trebaju rekonstruirati i proći konceptualnu promjenu do znanstvenih koncepcija (Lukša, 2011). Za ostvarenje konceptualnog pristupa nastavi biologije, potrebno je definirati konceptne okvire. Konceptni okviri se u svijetu predlažu na nacionalnoj razini kao standardi za prirodne znanosti (Lukša, 2011). Konceptni okvir ima ulogu formiranja temelja za razumijevanje pojedine znanstvene discipline, koji se potom sadržajno prilagođavaju učenicima na temelju njihovih mogućnosti, interesa, potreba i dobi (Lukša i sur, 2013). Konceptni okviri sadrže temeljne koncepte (makrokoncepte) koje učenici trebaju razumjeti, a koji se u nastavi mogu razraditi na nižim razinama. Wood (2009) navodi da u nastavi biologije, nakon primjene konceptnih okvira i konceptualnog pristupa u nastavi, više nije potrebno obrazlagati sve primjere za neki koncept, već je princip dovoljno objasniti na jednom primjeru te očekivati od učenika da ga razumiju i primijene na druge primjere. Od nastavnika se očekuje da iz svakog makrokoncepta ili ključnog koncepta definiranog prema korištenom konceptualnom okviru, definira specifične ishode učenja i osnovne koncepte, a učenje treba temeljiti na međusobnom povezivanju koncepata i njihovom integriranju na višoj razini (Wood, 2009). Pritom se iz nastave isključuju detalji i brojnost činjenica u nastavnom sadržaju.

U Hrvatskoj se, kao i u svijetu, pokazalo da učenici u nastavi biologije uglavnom ostvaruju dobre rezultate u pitanjima u kojima se provjeravaju njihove kompetencije na nižim kognitivnim razinama 
(Garašić i sur, 2013; Wood, 2009; Momsen i sur, 2010). Uzrok tome djelomično se može pronaći u načinu ispitivanja, jer nastavnici/ispitivači često sastavljaju pitanja veće razine težine, ali na nižim kognitivnim razinama te im je teško uočiti razliku između težine zadatka i njegove kognitivne razine. Nekoliko je istraživanja pokazalo da se utvrđivanjem učeničkih miskoncepcija i promjenama nastavnog pristupa na temelju tih rezultata može smanjiti broj učeničkih miskoncepcija (Michael i sur, 2002; Modell, 2000; Modell i sur, 2005). Navedena i slična istraživanja nude rezultate koji pokazuju veliku sličnost i dosljednost miskoncepcija na širokom uzorku, stoga se mogu iskoristiti kao polazišna točka za kreiranje nastave $s$ promijenjenim načinom poučavanja u svrhu postizanja konceptualne promjene kod učenika.

S obzirom da se još uvijek nedovoljno ispituje konceptualno razumijevanje učenika, prethodno opisani biološki konceptni okviri trebali bi se koristiti kao instrument upravo za oblikovanje zadataka kojima će se provjeravati konceptualno razumijevanje. $U$ tu svrhu nastavnici često u nastavu uvode istraživački pristup, koji se međutim nije pokazao uspješnim za uklanjanje pogrešnih koncepcija (Barker i Carr, 1989). Isti autori predlažu konstruktivistički pristup nastavi u kojem se utvrđuju predkoncepcije učenika, a na primjeru fotosinteze utvrđeno je da čak $71 \%$ učenika po završetku nastave postiže konceptualno razumijevanje. Osim toga, nastavne strategije koje zahtijevaju aktivni angažman učenika smatraju se korisnijima i efikasnijima u otklanjanju miskoncepcija i dostizanju konceptualne promjene. Jedan od najučinkovitijih pristupa jest učenje otkrivanjem, koje povećava mogućnosti suočavanja s miskoncepcijama (Lorenzo i sur, 2006, Lukša, 2011), a kao rezultat ima bolje vještine u znanstvenom rasuđivanju i konceptualno razumijevanje. Bez obzira na to što se stručnjaci slažu da je ova strategija poučavanja izrazito korisna i efikasna, njena primjena u nastavi u svim razinama obrazovanja još uvijek nije raširena.

Pri ispitivanju konceptualnog razumijevanja, pitanja se trebaju formirati tako da se u središte postavi osnovni koncept za određeno područje, a distraktori bi trebali biti razvijeni tako da prikazuju široko prihvaćene miskoncepcije (Lukša, 2011). Tanner i Allen (2005) tvrde kako su učenički pogrešni odgovori najbolji alat u poučavanju i kreiranju uspješnog učenja i usvajanja znanja. Zbog toga je važno učenike ispitati prije usvajanja nekog nastavnog sadržaja, da bi se utvrdile njihove predkoncepcije i miskoncepcije, te na kraju nastavnog ciklusa utvrdilo je li postignuta konceptualna promjena. Korištenje konceptualnih mapa u nastavi omogućuje jasniji uvid u razlike među učeničkim strukturama znanja (Ruiz-Primo i sur, 2001) te se mogu primijeniti kao alat za procjenu znanja i konceptualnog razumijevanja kod učenika (Novak i Cañas, 2008). Korištenje konceptualnih mapa pri učenju kod učenika hrvatskih srednjih škola pokazalo se uspješnom metodom učenja, jer su učenici koji su učili uz konceptualne mape u usporedbi s tradicionalnim metodama pokazali bolje rezultate pri ispitivanju znanja viših kognitivnih razina, a pokazana je i bolja retencija znanja (Latin i sur, 2016).

U Republici Hrvatskoj se kao mjerilo uspješnosti obrazovanja u prirodoslovnom području, a tako i biologiji, u posljednje vrijeme koriste rezultati raznih ispita koje provodi Nacionalni centar za vanjsko vrednovanje obrazovanja te PISA istraživanja provedena 2009., 2012. i 2015. godine (Braš Roth i sur, 2017). Međutim, ispitivanja znanja hrvatskih učenika osnovnih i srednjih škola (nacionalni ispiti 2007./2008.; državna matura od 2008. do 2015.) velikim dijelom zasnivaju se na pitanjima različite težine, međutim većinom orijentiranima na reprodukciju znanja, a vrlo malo na provjeru primjene znanja i vještina (Radanović i sur, 2010, 2017a; Ristić-Dedić i sur, 2011). Na Nacionalnim ispitima (2007./2008.), gdje su sastavljači pitanja bili nastavnici s dugogodišnjom praksom, vidi se relacija programa nastave biologije u školi koji se temelji na velikom opsegu činjenica i pojmova, a ne na 
gradnji konceptualnog razumijevanja. Radanović i sur. (2010) navode kako se na temelju analize navedenih ispita preporuča izmjena nastavnog programa prirode i biologije, koja bi se trebala orijentirati na konceptualno razumijevanje i razvoj prirodoslovne pismenosti (Radanović i sur, 2017a i b).

Pitanja koja se pojavljuju na Županijskom natjecanju iz biologije povezana su s nastavnim sadržajem biologije u 7. i 8. razredu osnovne škole, propisanim Nastavnim planom i programom za osnovnu školu (MZOŠ, 2006). Nastavni sadržaji i nazivi nastavnih tema u ovom radu odnose se na teme propisane istim dokumentom. Makrokoncept Razmnožavanje i razvoj organizma zastupljen je u nastavnim sadržajima prirode i biologije za učenike od 4. do 8. razreda osnovne škole. Ključni koncepti razmnožavanja pojavljuju se u različitoj zastupljenosti u nastavnim sadržajima za pojedini razred, a oni bi se kroz nastavu biologije trebali međusobno povezivati i nadograđivati da bi se uspješno izgradilo konceptualno razumijevanje njih samih, ali i krovnog makrokoncepta.

Uz redovite pisane provjere znanja u nastavi, jedan od načina provjere znanja su i natjecanja učenika. Natjecanje se organizira uz odobrenje MZO prema uputama u Katalogu natjecanja (HBD, 2017). Natjecanje učenika osnovnih škola u znanju biologije provodi se pisanim ispitima koje izrađuje Državno povjerenstvo (HBD, 2017), a prema Nastavnom planu i programu za osnovnu školu (2006) te u skladu s udžbenicima koje je odobrilo Ministarstvo znanosti i obrazovanja za tekuću školsku godinu. Učenici koji sudjeluju na natjecanju iz biologije jesu učenici s velikim interesom za nastavu biologije koji u pravilu ostvaruju izvrsne rezultate u nastavi. Ispitivanje znanja na natjecanju učenika u biologiji obavlja se pisanim ispitom koji sadrži pitanja različitih tipova, različitih kognitivnih razina i razina zahtjevnosti zadatka (Radanović i sur, 2013). Na osnovu analize uspješnosti učenika na Županijskom natjecanju iz biologije za 7. razred 2015. godine (Begić i sur, 2016) sudjelovalo je 148 učenika, a ukupna prosječna riješenost ispita jest $64,44 \%$. Prema županijama, prosječno su najuspješniji učenici Krapinsko-zagorske županije. Pritom su dječaci bili uspješniji s prosječnom riješenosti provjere 64,37 $\%$, dok su djevojčice ostvarile prosječnu riješenost provjere 62,02 \%. Prema Lugar i Mustać (2016) na Županijskom natjecanju iz biologije 2015. godine sudjelovalo je 113 učenika 8. razreda. Najveći broj učenika dolazi iz Grada Zagreba. Ukupna prosječna riješenost ispita je 69,90 \%. Prema županijama, najuspješniji su bili učenici Krapinsko-zagorske županije. Pritom su uspješniji bili dječaci sa srednjom riješenosti provjere 71,56 \%, dok su djevojčice ostvarile srednju riješenost 69,13 \%.

Analiza odgovora učenika na pitanja postavljena na pisanom ispitu Natjecanja iz biologije omogućuje uvid u pogrešno razumijevanje nastavnih sadržaja biologije kod izrazito uspješnih učenika te predviđanje miskoncepcija koje treba imati na umu pri planiranju nastave biologije u školama.

U provedenim analizama nije obuhvaćena detaljna analiza odgovora učenika i njihovo značenje za učenje i poučavanje biologije. Stoga je cilj ovog istraživanja je analizirati učeničke odgovore na pitanja pisanog ispita znanja na Županijskom natjecanju iz biologije da bi se utvrdila usvojenost $i$ konceptualno razumijevanje makrokoncepta Razmnožavanje i razvoj organizma među učenicima 7. i 8. razreda osnovnih škola. U svrhu ostvarenja cilja, istraživanjem se želi:

utvrditi ujednačenost procjena između županijskog i državnog povjerenstva u procjeni odgovora učenika

analizirati učeničke odgovore na način da se utvrdi točnost i razina razumijevanja svakog pojedinog odgovora uz pitanja vezana za razumijevanje životnog ciklusa i oplodnje te odredi značenje odgovora u kontekstu konceptualnog razumijevanja. 
Utvrđeni problemi pri učenju i poučavanju ukazat će nastavnicima biologije na promjene koje su neophodne u planiranju nastave u osnovnoj školi da bi se uspješno otklonile miskoncepcije $i$ omogućila kvalitetna izgradnja koncepta Razmnožavanje i razvoj organizma.

\section{MATERIJALI I METODE}

Za potrebe istraživanja provedena je analiza ispita $20 \%$ najuspješnijih učenika na Županijskom natjecanju iz biologije 7. razreda osnovne škole 2017. godine, te 7. i 8. razreda 2015. godine. Uzorak od $20 \%$ je prigodan jer su samo testovi najuspješnijih učenika prema rezultatima dostavljeni Držanom povjerenstvu koje je provelo ponovno ispravljanje s ciljem usklađivanja kriterija u svim Županijama. Analizirani su rezultati odgovora pa izdvojenim pitanjima koja provjeravaju makrokoncept Razmnožavanje i razvoj organizma. Za izdvojena pitanja određen je tip zadatka, ključni i specifični koncepti 1 i 2 te ishodi učenja koji se provjeravaju prema Ispitnom katalogu državne mature iz biologije (NCVVO, 2017), kao postojećem konceptualnom okviru učenja biologije u Republici Hrvatskoj. Svaki odgovor dodatno je procijenjen prema kriterijima točnosti i razini razumijevanja prema prilagođenoj metodologiji Radanović i sur. (2017). Za dodatnu analizu i interpretaciju odgovora učenika u kontekstu konceptualnog razumijevanja bioloških koncepata korištena je metodologija specifičnog kodiranja biološkog značenja točnih odnosno netočnih učeničkih odgovora prema Radanović i sur. (2016.).

Tablica 1. Skale za procjenu točnosti, razine razumijevanja te problema i miskoncepcija u učeničkim odgovorima

\begin{tabular}{|c|c|c|c|c|c|}
\hline TOČNOST & $T$ & RAZINA RAZUMIJEVANJA & $\mathrm{RR}$ & PROBLEMI I MISKONCEPCIJE & $\mathrm{PIM}$ \\
\hline napredno razmišljanje & 8 & besmisleno & 0 & moguća miskoncepcija & 3 \\
\hline potpuni traženi odgovor & 7 & $\begin{array}{c}\text { konceptualno } \\
\text { nerazumijevanje }\end{array}$ & 1 & $\begin{array}{c}\text { problem pri učenju ili } \\
\text { poučavanju }\end{array}$ & 2 \\
\hline djelomično točno & 6 & reprodukcija & 2 & problem zbog memoriranja & 1 \\
\hline $\begin{array}{c}\text { krivo ili nespretno napisano, ali točno } \\
\text { razmišljanje }\end{array}$ & 5 & prepoznavanje & 3 & $\begin{array}{l}\text { točno ili djelomično točno } \\
\text { razmišljanje }\end{array}$ & 0 \\
\hline ispravljeno $u$ točno & 4 & primjena & 4 & nema odgovora & 9 \\
\hline reproduktivno, djelomično točno & 3 & $\begin{array}{l}\text { djelomično konceptualno } \\
\text { razumijevanje }\end{array}$ & 5 & & \\
\hline točno ispravljeno u netočno & 2 & konceptualno razumijevanje & 6 & & \\
\hline prenesen dio pitanja & 1 & nema odgovora & 9 & & \\
\hline netočno & 0 & & & & \\
\hline nema odgovora & 9 & & & & \\
\hline
\end{tabular}

Prema provedenoj analizi izdvojena su pitanja vezana uz koncept Razmnožavanje i razvoj organizma te utvrđene miskoncepcije učenika kao i pogrešno razumijevanje nastavnih sadržaja vezanih uz taj koncept. Učenici su prema ukupnom uspjehu u rješavanju provjere znanja na županijskom natjecanju podijeljeni u klase riješenosti na osnovu postignutog postotnog uspjeha pri rješavanju provjera prema Radanović i sur. (2017) te je time omogućeno utvrđivanje miskoncepcija na razini pogrešnih odgovora na pitanja u pisanoj provjeri znanja. O pojavi miskoncepcija možemo govoriti kada se pogrešno razumijevanje kroz učenički odgovor identificira podjednako kod svih skupina učenika prema klasama riješenosti provjere, a osobito ako se neko pogrešno razmišljanje podjednako pojavljuje kod učenika koji su provjeru riješili slabo i onih koji su bili vrlo uspješni. Za pitanja vezana uz makrokoncept Razmnožavanje i razvoj organizma određena je kognitivna razina i procjena težine pitanja prema Radanović i sur. (2017). S obzirom da su uz koncepte životnog ciklusa i oplodnje uočeni problemi pri odgovorima učenika na više pitanja, upravo su ta pitanja izdvojena i detaljno analizirana s ciljem utvrđivanja razloga uočenih problema kao i mogućnosti za njihovo eventualno otklanjanje.

Statističke analize i grafički prikazi su izrađeni uz pomoć programskog paketa analize podataka Microsoft Excel i on-line StatsToDo. Za utvrđivanje distribucije pogrešnih odgovora između klasa 
riješenosti svakog pitanja korišten je $\chi^{2}$ test (Chi Sq), a razlike frekvencija pojedinih klasa učenika prema ukupnoj uspješnosti kao i parcijalnih odgovora na pitanja analizirane su Friedmanovom dvosmjernom analizom varijance za neparametrijske podatke (F). Zbog nedovoljno velikog uzorka, kada je u klasama bilo manje od 3 učenika (slika 1), te su klase izuzete iz analize pri utvrđivanju postojanja miskoncepcija na osnovu pogrešnih odgovora učenika. Povezanosti varijabli utvrđene su uz pomoć indeksa korelacije, Pearsonov koeficijent korelacije $(r)$ u slučajevima linearne povezanosti i normalne distribucije, a pomoću Spearmanovog koeficijentna korelacije ( $\rho$ ) utvrđena je povezanost uspješnosti pri rješavanju provjere $i$ odgovarajuće kognitivne razine pitanja. Pearsonovim koeficijentom korelacije određena je međusobna povezanost vrjednovanja učeničkih odgovora na županijskim natjecanjima između županijskog i državnog povjerenstva. Kod interpretacije rezultata korelativne povezanosti korištena je skala prema Hopkinsu (2000).

\section{REZULTATI}

Procjena točnosti odgovora i vrjednovanje gotovo se u potpunosti podudara kod nastavnika u županijskim povjerenstvima s nastavnicima u državnom povjerenstvu pri vrjednovanju provjera 2015. $(r=0,99)$. Za županijsko natjecanje 2017. godine utvrđena je visoka razina podudarnosti procjene točnosti učeničkih odgovora na razini županijskog i državnog povjerenstva $(r=0,58)$.

Neslaganja županijskog i državnog povjerenstva kod procjene i bodovanja odgovora učenika na županijskom natjecanju 2017. godine vezana su uz pitanja otvorenog tipa II. i III. kognitivne razine. U tim su se slučajevima učenici imali priliku slobodno izražavati što je utjecalo na procjenu točnosti odgovora koja se razlikuje na razini županijskog i državnog povjerenstva. Moglo se uočiti kako državno povjerenstvo u većini slučajeva učeničke odgovore na pitanja otvorenog tipa boduje $s$ više bodova od županijskog povjerenstva. Razlog tome može se pronaći u strogom tumačenju smjernica za vrjednovanje odgovora od strane nastavnika u županijskom povjerenstvu, a bez dovoljno jasne diskusije o drugim mogućnostima tumačenja odgovora. U slučajevima gdje se dodijeljeni broj bodova na dvije razine povjerenstva razlikuje, nastavnici u županijskom povjerenstvu nisu uvažavali točne odgovore učenika koji nisu izraženi na način vrlo sličan ili jednak predloženom točnom odgovoru u smjernicama za vrjednovanje. Državno povjerenstvo uvažavalo je sve točne odgovore učenika, ako je njihovo značenje bilo odgovarajuće za postavljeno pitanje. Također se moglo uvidjeti kako se neslaganja u bodovanju uglavnom pojavljuju kod učenika iz istih županija. U slučajevima kada je državno povjerenstvo umanjilo broj dodijeljenih bodova učenicima, radilo se o pogrešnom vrjednovanju odgovora na pitanja otvorenog tipa, gdje su učenici trebali odgovoriti jednom riječju ili brojem. U tim su pitanjima točni odgovori bili precizno propisani u smjernicama za vrjednovanje, a nastavnici županijskog povjerenstva priznavali su i drugačije odgovore kao točne.

Na Županijskom natjecanju iz biologije 2017. godine sudjelovalo je 162 učenika 7. razreda. Najveći broj učenika koji su sudjelovali na županijskim natjecanjima za 7. razred dolazi iz Međimurske županije i Grada Zagreba. Za županijsko natjecanje 2017. godine, ukupna prosječna riješenost ispita jest 69,51 \%. Prosječno su najuspješniji bili učenici Zagrebačke županije. Kao i 2015. godine, dječaci su prosječno bili uspješniji u rješavanju ispita od djevojčica, s prosječnom riješenosti provjere $73,56 \%$, dok je kod djevojčica prosječna riješenost iznosila $68,78 \%$. Takav rezultat upućuje da na natjecanje iz biologije pristupaju djevojčice u većem rasponu sposobnosti te manji broj visoko zainteresiranih dječaka. 
U svim izdvojenim pitanjima određena je velika povezanost vrjednovanja odgovora županijskog i državnog povjerenstva, kod pitanja višestrukog izbora ili serije alternativnog izbora, što je bilo i očekivano, s obzirom da se radi o pitanjima zatvorenog tipa, gdje je interpretacija odgovora vrlo jasna i način dodjele bodova precizno opisan. Mala odstupanja u vrjednovanju provjere za 8. razred 2015. nastala su zbog drugačijeg tumačenja učeničkih odgovora, kada je državno povjerenstvo uglavnom smanjivalo broj dodijeljenih bodova zbog neprecizno izraženog odgovora na pitanje.

S obzirom na povezanost kognitivne razine zadatka i uspješnosti učenika u njihovu rješavanju, u provjeri za 7. razred 2015. godine utvrđena je značajna negativna korelacija $(\rho=-0,57 ; p<0,05)$, kao i za provjeru 2017. ( $\rho=-0,53 ; p<0,05)$. U obje provjere učenici su vrlo uspješno rješavali zadatke I. kognitivne razine, a najmanju riješenost imala su pitanja III. kognitivne razine. Nije utvrđena statistički značajna korelacija kognitivne razine pitanja s uspješnosti u rješavanju pitanja 8 . razreda ( $\rho$ $=0,13 ; p=>0,5)$. Učenici su prosječno podjednako uspješno rješavali pitanja I. i II. kognitivne razine, dok na provjeri nije bilo pitanja III. kognitivne razine.

Prema ukupnom uspjehu učenika u rješavanju provjera, 20 \% najuspješnijih učenika koji sudjeluju u županijskim natjecanjima u znanju biologije raspoređeni su u klase riješenosti više od 30 \%, a najveći broj učenika rješava provjere u rasponu riješenosti od $61 \%$ do $90 \%$, ovisno o kognitivnim zahtjevima provjere (slika 1).

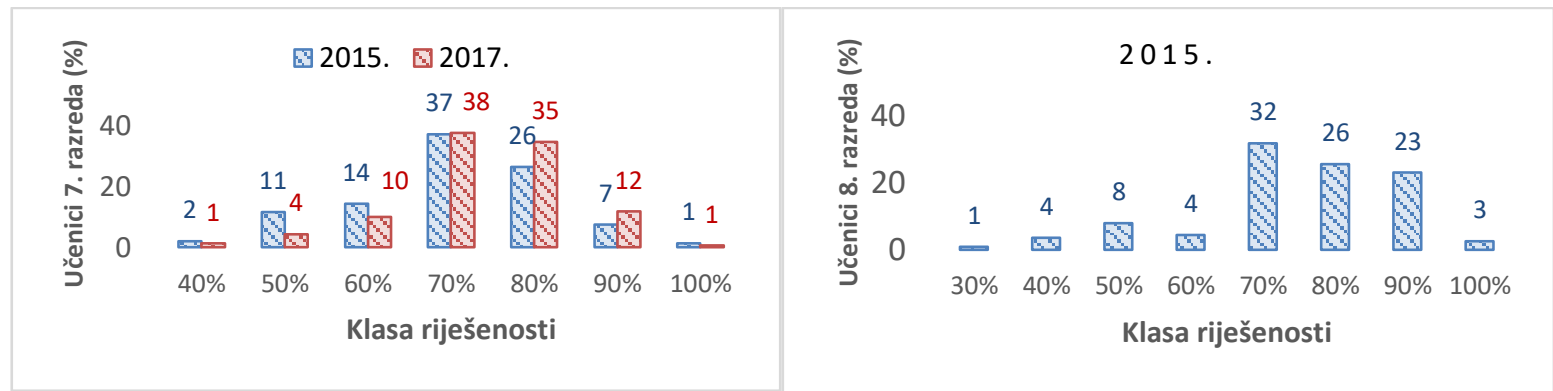

Slika 1 Udio učenika prema klasama riješenosti provjere na Županijskim natjecanjima za 7. i 8. razred

Prema učeničkim odgovorima u ovom radu prikazano je odabranih pet pitanja na osnovu distribucije netočnih odgovora uz koja je utvrđeno postojanje problema pri učenju ili poučavanju te mogućnost miskoncepcije uz koncepte životni ciklus stanice i oplodnja te je analizirana raspodjela učenika kod kojih se javljaju miskoncepcije s obzirom na klase riješenosti provjere.

\section{Natjecanje za 7. razred 2015. godine}

Pitanje 22. Prouči dijagram koji prikazuje životni ciklus žabe i dopuni ga upisivanjem odgovarajućih pojmova na prazne crte. $\mathrm{Na}$ prikazanom su dijagramu brojevima označeni procesi, a slovima vrste (tipovi) stanica koje tim procesima nastaju i čiji je broj kromosoma naveden u zagradi. U zagradu uz zigotu također treba upisati odgovarajuću oznaku za broj kromosoma. Napomena: Iste pojmove možeš koristiti više puta.

Točan odgovor: 1 mejoza, A spolne stanice, zigota 2n, 2 mitoza, B tjelesne stanice, 3 mitoza, 4 mitoza

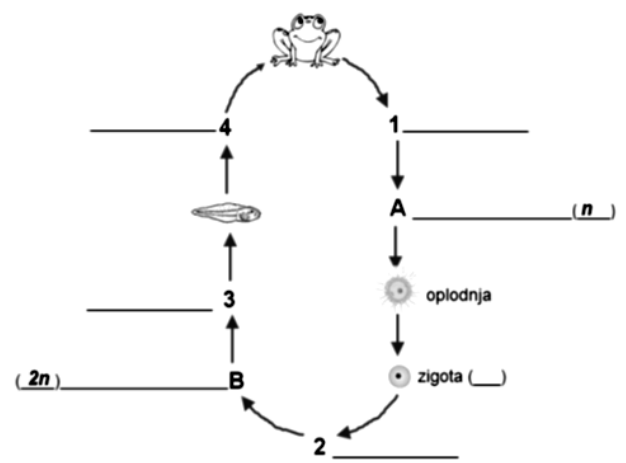

Pitanje je usko vezano uz nastavne teme Stanica s jezgrom, Stanične diobe i Vodozemci koje su dio nastavnog sadržaja biologije u 7. razredu. Na pitanje je $27 \%$ učenika dalo potpuno točan odgovor (slika 2). 


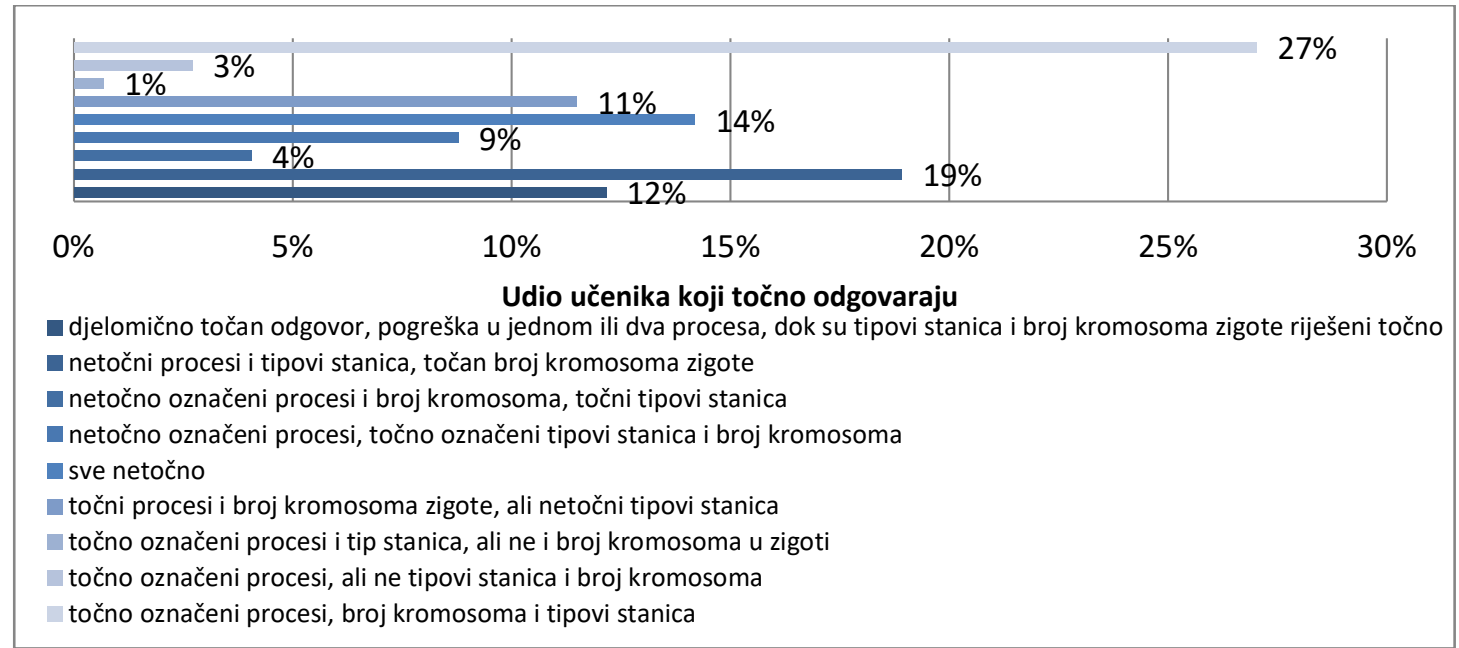

Slika 2. Specifično kodiranje odgovora učenika na 22. pitanje na Županijskom natjecanju iz biologije 2015. godine

Potpuno točan odgovor na ovo pitanje ukazuje na dobro usvojeno reproduktivno znanje o životnom ciklusu žabe $i$ životnom ciklusu stanice koje se odnosi na broj kromosoma i tipove stanica u određenom dijelu ciklusa, te razumijevanje uloge mitoze u rastu i razvitku živih bića kao i uloge mejoze u razmnožavanju (tablica 3 ).

Tablica 2 Karakteristike 22. pitanja na Županijskom natjecanju iz biologije 2015. godine

\begin{tabular}{|c|c|c|}
\hline Tip pitanja & Navođenje iz crteža & Neophodni koncepti za odgovor učenika \\
\hline Makrokoncept & Razmnožavanje i razvoj organizma & \multirow{3}{*}{$\begin{array}{l}\text { životni ciklus stanice, životni ciklus žabe, uloga } \\
\text { mitoze kod mnogostaničnih organizama, uloga } \\
\text { mejoze u razmnožavanju mnogostaničnih } \\
\text { organizama, uloga mitoze u razvoju } \\
\text { mnogostaničnih organizama promjena broja } \\
\text { kromosoma tijekom mejoze, važnost haploidnog } \\
\text { broja kromosoma u spolnim stanicama, oplodnja }\end{array}$} \\
\hline Koncept & Životni ciklusi organizma & \\
\hline $\begin{array}{l}\text { Ishodi učenja } \\
\text { (IK DM) }\end{array}$ & Opisati životni ciklus žabe. Analizirati životni ciklus stanice. & \\
\hline
\end{tabular}

Kroz specifično kodiranje $\mathrm{i}$ analizu točnosti ustanovljen je velik broj djelomično točnih učeničkih odgovora, stoga velik broj učenika pokazuje djelomično i potpuno konceptualno razumijevanje provjeravanih koncepata (slika 3). Razina razumijevanja reprodukcija i prepoznavanje odnosi se na dio pitanja u kojem učenici trebaju odrediti tip stanice (tjelesne ili spolne) prema već određenom broju kromosoma te ponuditi broj kromosoma u zigoti. Djelomično konceptualno razumijevanje pokazuju učenici koji su pogriješili u imenovanju jednog ili dva procesa u životnom ciklusu, ali su odgovorima pokazali dobro razmišljanje.

Od učenika koji su odgovorili netočno, u najvećoj mjeri uočava se problem u učenju i poučavanju, a u manjem omjeru postojanje moguće miskoncepcije (slika 3). Moguća miskoncepcija povezana je sa životnim ciklusom stanice, jer neki učenici smatraju da je broj kromosoma u zigoti i tjelesnim stanicama haploidan, a u spolnim stanicama diploidan. Velik broj učenika koji su dali takav pogrešan odgovor ipak je dobro odgovorilo na dijelove pitanja koji su se odnosili na nazive procesa (staničnih diobi), čime potvrđuju svoje reproduktivno znanje. Miskoncepcija vjerojatno nastaje tijekom učenja, jer učenici pokazuju nerazumijevanje važnosti haploidnog broja kromosoma kod spolnih stanica kao i diploidnog broja kromosoma u zigoti, što ukazuje da ne povezuju nastanak zigote s nastankom nove jedinke i održavanjem stalnosti broja kromosoma vrste. 


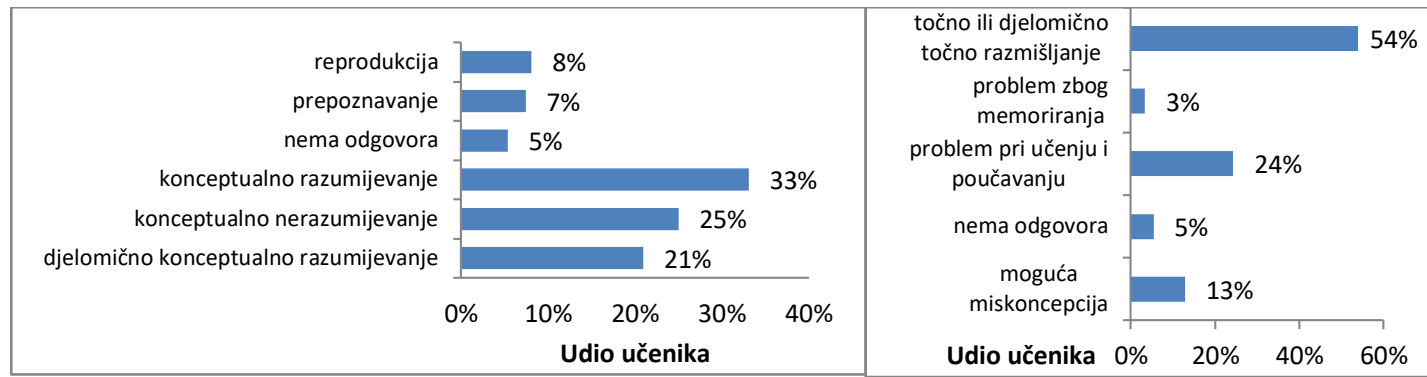

Slika 3 Analiza razine razumijevanja životnog ciklusa žabe i životnog ciklusa stanice te problema i miskoncepcija prema odgovorima učenika na 22. pitanje.

Nije utvrđena statistički značajna razlika u pojavi moguće miskoncepcije prema različitim klasama riješenosti $\left(\chi^{2}=1,58, d f=18 ; p=0,99\right)$. Pogrešno razmišljanje ne javlja se u podjednakim frekvencijama kod svih klasa učenika, ali i kod vrlo uspješnih učenika javlja se u 69 \% njihovih odgovora (slika 4). Zbog prirode pitanja, uz koje nije traženo objašnjenje, u ovom slučaju ne možemo govoriti sa sigurnosti o miskoncepciji, nego o nemogućnosti povezivanja zbira podataka i nedostatku znanja na I. i Il. kognitivnoj razini.

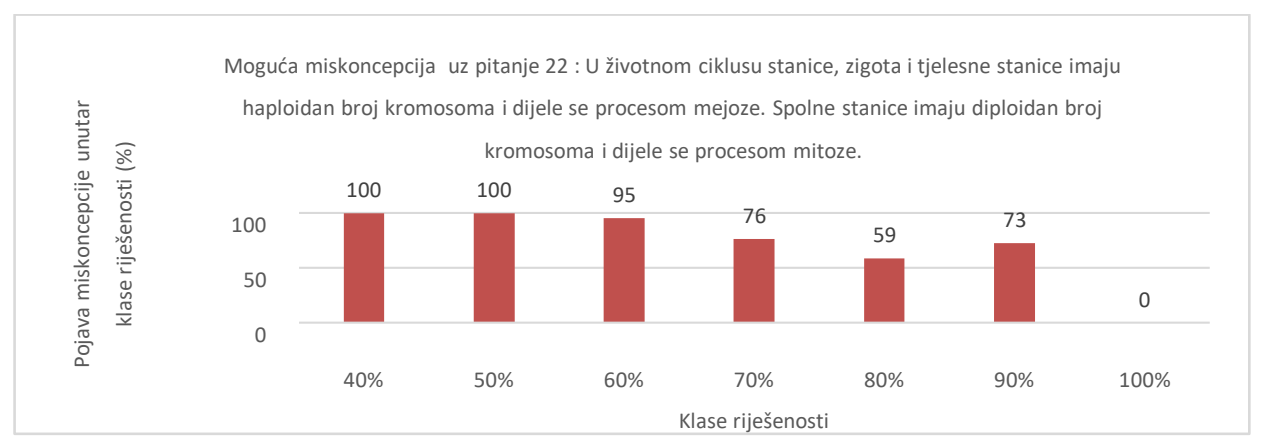

Slika 4 Udio učenika kod kojih se pojavljuje miskoncepcija uz pitanje 22 na natjecanju 2015. godine prema klasama riješenosti provjere

\section{Natjecanje za 7. razred 2017. godine}

Pitanje 12. Za proces razmnožavanja pčela specifično je da se ženke (radilice i matice) razvijaju iz oplođenih jajnih stanica, a mužjaci (trutovi) iz neoplođenih jajnih stanica. Odredi jesu li turdnje o potomcima pčela točne ili netočne.

a) Svi trutovi u stanicama imaju potpuno jednake gene. (N)

b) Sve radilice istog legla u stanicama imaju jednake gene.(N)

c) Sve jajne stanice koje polažu matice imaju dvostruki broj kromosoma (N)

d) Stanice koje izgrađuju tijelo matica imaju dvostruki broj kromosoma.(T)

e) Stanice koje izgrađuju tijelo trutova imaju polovičan broj kromosoma. (T)

Za uspješno rješavanje 12. pitanja, učenici su trebali primijeniti znanja o razmnožavanju i nasljeđivanju, te o ulozi oplodnje u procesu razmnožavanja. Učenici ne uče da se organizam može razviti iz neoplođene stanice, ali je zadatak usmjeren na zaključivanje da ako nije došlo do oplodnje da broj kromosoma neće biti dvostruk. Potrebno je reproduktivno znanje o broju kromosoma kod tjelesnih i spolnih stanica (tablica 4) za pojedinačni odgovor, ali pitanje u cjelini daje dobru informaciju o konceptualnom razumijevanju učenika veze oplodnje i broja kromosoma. lako nije direktno sadržano u nastavnom programu, ali dovoljno informacija uvodnog teksta omogućuje primijenu znanja vezanog uz nastavne teme u 7. razredu: Stanične diobe, Kukci i ostali člankonošci, a može se povezati i s nastavom prirode $\mathrm{u} 5$. razredu, posebice $\mathrm{s}$ temom Razmnožavanje i ponašanje životinja. 
Tablica 3. Karakteristike 12. pitanja na Županijskom natjecanju iz biologije 2017. godine

\begin{tabular}{|c|c|c|}
\hline Tip pitanja & Zadatak serije alternativnih odgovora & Neophodni koncepti za odgovor učenika \\
\hline Makrokoncept & Razmnožavanje i razvoj organizma & \multirow{3}{*}{$\begin{array}{l}\text { oplodnja, razvitak iz oplođene jajne } \\
\text { stanice, razvitak iz neoplođene jajne } \\
\text { stanice, broj kromosoma u tjelesnim i } \\
\text { spolnim stanicama, promjena broja } \\
\text { kromosoma u mejozi, nasljeđivanje gena } \\
\text { od roditelja, raspodjela kromosoma u } \\
\text { nove stanice tijekom mejoze, stalnost } \\
\text { broja kromosoma vrste }\end{array}$} \\
\hline Koncept & Nasljeđivanje na razini organizma & \\
\hline Ishodi učenja (IK DM) & $\begin{array}{l}\text { Analizirati odnose među genima i njihov utjecaj na razini } \\
\text { organizma ili pojedine osobine. Povezati stalnost broja, } \\
\text { građe i oblika kromosoma s definicijom vrste } \\
\text { kao reproduktivno izolirane skupine organizama }\end{array}$ & \\
\hline
\end{tabular}

Od 162 učenika koji čine 20 \% najuspješnijih učenika na natjecanju, njih $11 \%$ dalo je točan odgovor na svih 5 tvrdnji (slika 5). S obzirom da svih pet tvrdnji navedenih u zadatku provjeravaju isti koncept, razina razumijevanja koncepta analizirana je za sve tvrdnje kao cjelinu. Najveći broj učenika dalo je točne odgovore na 3 od 5 tvrdnji (slika 5), što ukazuje da kod njih ne postoji potpuno konceptualno razumijevanje već su odgovori dani na razini prepoznavanja i reprodukcije, što potvrđuje veći broj točnih odgovara na tvrdnje koje su vezane uz sadržaje koji se uobičajeno poučavaju. Djelomično konceptualno razumijevanje pokazuje $35 \%$ učenika koji su točno odgovorili na 4 od 5 tvrdnji. U podjednakim udjelima (slika 5) je kod učenika sa Županijskog natjecanja 2017. potvrđena uspješnost izgradnje koncepta broja kromosoma (35\%) te ostvareno razumijevanje karakteristika gena (38\%).

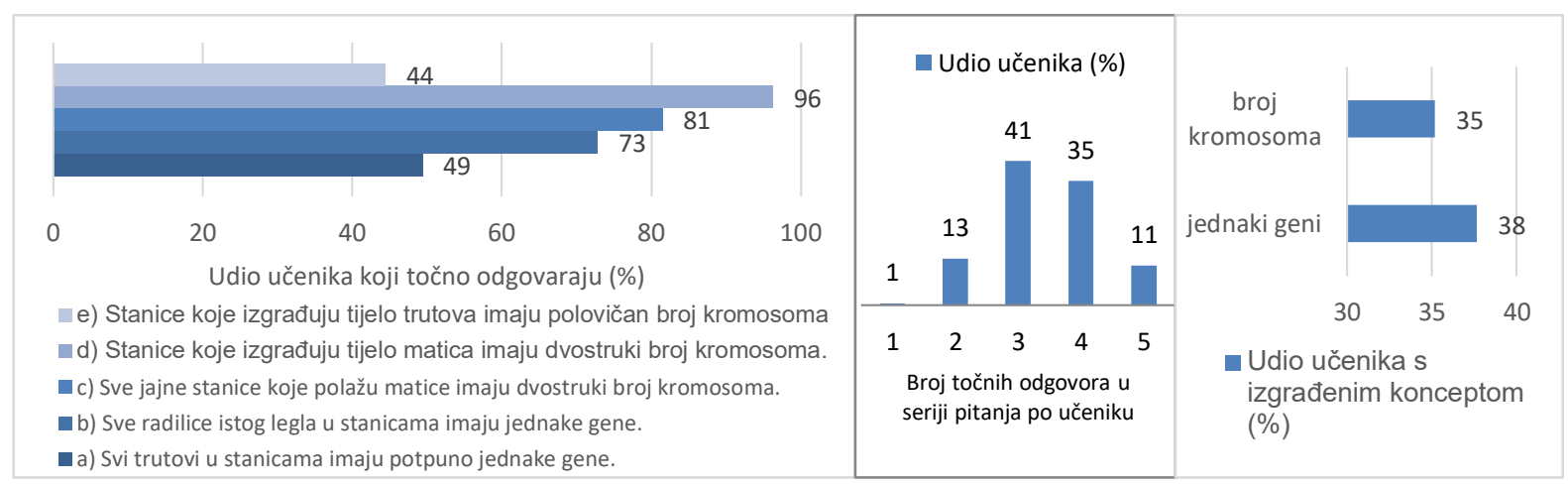

Slika 5 Odgovori učenika na seriju pitanja koji provjeravaju koncept broja kromosoma i karakteristika gena

Prema analiziranim rezultatima polovica odgovora na pitanje 12.a nije ispravno (slika 5) što ukazuje na pogrešno razumijevanje procesa mejoze i raspodjele kromosoma koji nose različite varijante gena u spolne stanice koje nastaju mejozom. Kod manjeg udjela učenika javlja se moguća miskoncepcija da svi trutovi istog legla imaju jednake gene (slika 6), koja nastaje zbog nerazumijevanja nasljeđivanja na razini stanice, $\mathrm{tj}$. raspodjele kromosoma $\mathrm{s}$ različitim varijantama gena $\mathrm{u}$ novonastale spolne stanice. Moguća miskoncepcija javlja se u svim klasama riješenosti provjere, osim kod vrlo uspješnih učenika, međutim u različitim frekvencijama. Nije utvrđena statistički značajna razlika u pojavi moguće miskoncepcije prema različitim klasama riješenosti (slika 6). U najvećoj frekvenciji javlja se kod učenika $70 \%$ i $80 \%$ klase riješenosti, što ukazuje na problem u učenju i poučavanju, a ne na postojanje miskoncepcije.

Učenici (27\%) koji su pogrešno odgovorili na pitanje 12.b pokazuju potpuno nerazumijevanje značenja spolnog razmnožavanja, tj. oplodnje, zanemaruje se prisutnost gena naslijeđenih od drugog roditelja, pokazuje se nerazumijevanje procesa mejoze i raspodjele kromosoma u spolne stanice, kao što je objašnjeno kod tvrdnje 12.a. Veći udio učenika dao je točan odgovor na pitanje 12.c (slika 5). Učenici koji su pogrešno odgovorili na ovo pitanje pokazuju nepoznavanje i nerazumijevanje važnosti mejoze u nastanku spolnih stanica, tj. važnost jednostrukog broja kromosoma za spolne stanice. $19 \%$ učenika ne razumije važnost da spolne stanice uvijek imaju haploidan (polovičan) broj kromosoma. 
Učenici bi u sedmom razredu trebali razumjeti važnost haploidnog broja kromosoma kod spolnih stanica i uloge takvog broja kromosoma u oplodnji, odnosno nastanku zigote. Učenici koji su ponudili odgovor da je ova tvrdnja točna mogli su ga ponuditi jer ne razumiju važnost broja kromosoma u spolnim stanicama ili smatraju da spolne stanice matice moraju biti diploidne jer se iz neoplođenih jajnih stanica razvijaju trutovi. Kod manjeg broja učenika javlja se moguća miskoncepcija da sve jajne stanice koje polažu matice imaju dvostruki broj kromosoma (slika 6). Ova miskoncepcija izravno je povezana s nerazumijevanjem staničnih dioba i uloge promjene broja kromosoma tijekom nastanka spolnih stanica u mejozi. 96 \% učenika ponudilo je točan odgovor na pitanje 12.d (slika 5). Malobrojni učenici koji su pogrešno odgovorili na ovo pitanje pokazuju nerazumijevanje važnosti razlike broja kromosoma u tjelesnim i spolnim stanicama. Odgovor ukazuje na zanemarivanje uloge oplodnje kojom nastaje zigota, stanica $s$ dvostrukim brojem kromosoma, od koje procesom mitoze nastaju tjelesne stanice nekog organizma. Učenici u sedmom razredu trebaju razumjeti da se pri spominjanju dvostrukog broja kromosoma govori o parovima kromosoma, od kojih se jedan kromosom u paru nasljeđuje od majke, a drugi od oca, te da je takvo sparivanje kromosoma moguće upravo zbog oplodnje. Samo kod 4 \% učenika (slika 5) javlja se moguća miskoncepcija da tjelesne stanice matica imaju haploidan broj kromosoma, što je uzrokovano nerazumijevanjem procesa oplodnje. Učenici ovdje pokazuju i nedostatak reproduktivnog znanja o broju kromosoma u tjelesnim stanicama. $\mathrm{Na}$ pitanje 12.e netočno je odgovorilo više od polovice učenika (slika 5) koji pokazuju nerazumijevanje izostanka oplodnje kod razvitka trutova te se uočava nepovezivanje broja kromosoma u stanicama sa procesima stanične diobe $\mathrm{i}$ oplodnje, te utjecaja tih procesa na promjenu broja kromosoma $u$ stanicama. Trutovi se razvijaju iz neoplođenih jajnih stanica, stoga njihove tjelesne stanice imaju polovičan broj kromosoma, na osnovu čega su učenici trebali povezati da kod trutova, zbog takvog broja kromosoma i spolne stanice nastaju procesom mitoze.

Na temelju odgovora na pitanje 12.e i ostalih tvrdnji u pitanju 12, kod manjeg broja učenika javlja se moguća miskoncepcija da tjelesne stanice trutova imaju diploidan broj kromosoma. Miskoncepcija može nastati zbog nerazumijevanja razvitka organizma iz neoplođene jajne stanice. Nije utvrđena statistički značajna razlika u pojavi moguće miskoncepcije prema različitim klasama riješenosti $(\chi 2=$ $1,03 ; \mathrm{df}=19 ; \mathrm{p}=0,99)$. Moguća miskoncepcija javlja se podjednako kroz većinu klasa učenika prema riješenosti provjere (slika 6), osim kod vrlo uspješnih učenika. Stoga vrlo uspješni učenici pokazuju konceptualno razumijevanje za sve razine koncepta razmnožavanja i nasljeđivanja ispitivane u ovom zadatku, a kod ove tvrdnje za sve ostale skupine učenika možemo govoriti o pojavi miskoncepcije. Ova moguća miskoncepcija povezana je s ostalima prethodno navedenim mogućim miskoncepcijama $\mathrm{u}$ analizi pitanja 12, te se u nastavi može ukloniti detaljnim proučavanjem i ilustriranjem životnog ciklusa stanice, oplodnje i nasljeđivanja kod različitih organizama te izradom konceptualne mape sa središnjim konceptima životni ciklus stanice i oplodnja.

Na razini cijelog pitanja utvrđena je statistički značajna razlika između analiziranih netočnih odgovora učenika na pitanja prema klasama riješenosti $(F=13,87 ; d f=4 ; p<0,01)$. U skladu s ukupno izgrađenim konceptima kod učenika od 35\% i 38\% (slika 5), koji odgovaraju srednjoj riješenosti nacionalnih provjera u RH od oko 40 \% riješenosti (Garašić i sur, 2012), na razini cijelog pitanja nisu utvrđeni izraziti problemi. Značajne razlike javljaju se pri rješavanju pitanja 12.d i 12.e što ukazuje na probleme pri razumijevanju oplodnje te haploidnosti i diploidnosti stanica. Na osnovu distribucije pogrešnih odgovora prema klasama riješenosti miskoncepcije po parcijalnim pitanjima može se uočiti postojanje značajnih razlika između klasa riješenosti $(F=10,14 ; d f=4 ; 0,01<p<0,05)$, uz značajnu 
razliku rezultata najmanje uspješnih i najviše uspješnih učenika (razlika ${ }_{50 \%-90 \%}=15,5 ; p=0,05$ ), dok između ostalih klasa nema značajne razlike u riješenosti. Time se potvrđuje kvaliteta pitanja koja odvaja najuspješnije učenike prema sposobnosti kritičkog razmišljanja, a također da su učenici klase 90 \% zaslužno izdvojeni kao najuspješniji učenici na natjecanju (slika 6).

S obzirom na ukupan uspjeh riješenosti 12. pitanja koje je konceptualno povezano i provjerava konceptualno razumijevanje, možemo govoriti o postojanju miskoncepcija. Prva miskoncepcija tiče se distribucije gena u procesu mitoze i mejoze posebno pri nastanku gameta u kontekstu nasljeđivanja gena u leglu trutova, odnosno radilica uz pitanja 12.a i 12.b (slika 6). Moguća miskoncepcija uz nastanak gameta u kontekstu jajnih stanica koje izliježu matice javlja se u nižoj, ali podjednakoj frekvenciji kod svih klasa uspješnosti (slika 6). Učenici su uspješno usvojili diploidnost tjelesnih stanica višestaničnog organizma uz pitanje 12.d, ali slabije razumiju nastanak hiploidnih stanica u procesu mejoze uz kontekst stvaranja spolnih stanica, problemi su još uočljivi kod učenika slabijih klasa riješenosti (slika 6). Posljednja tvrdnja 12.e provjerava konceptualno razumijevanje spolnog $i$ nespolnog razmnožavanja na razini organizma, odnosno razvitak organizma iz oplođenih i neoplođenih jajnih stanica te su uz nju uočeni najveći problemi u razumijevanju, ali to je u skladu s provjerom za natjecanje kojim se trebaju izdvojiti najuspješniji učenici, koji cijeli zadatak, uključujući i posljednje pitanje, rješavaju u znatno većem broju od ostalih učenika, uz najmanje odstupanje razlike točnih odgovora od srednje vrijednosti (od 0,99 \% do 1,61 \%).

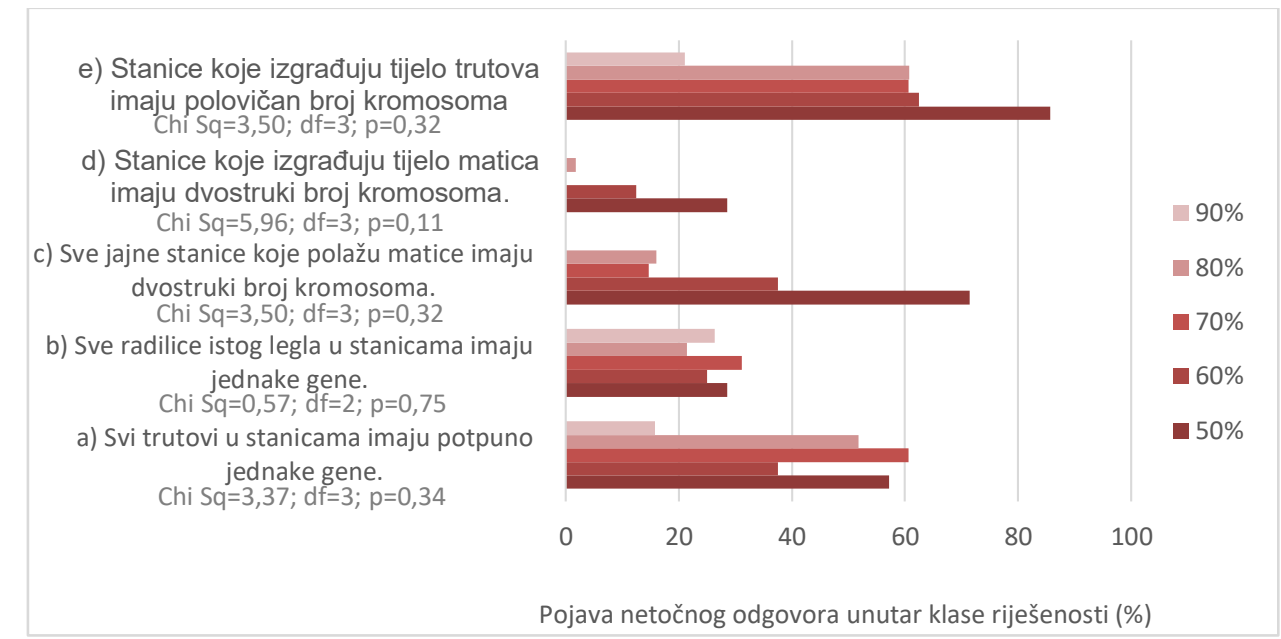

Slika 6 Udio učenika prema klasama riješenosti provjere kod kojih su zabilježeni problemi pri rješavanju pitanja 12 na natjecanju 2017. godine

\section{Natjecanje za 8. razred 2015. godine}

Pitanje 5. Na crtežu je prikazano rodoslovlje jedne obitelji kroz tri generacije.

a) Koji članovi obitelji imaju jednaku mitohondrijsku DNA? (Ana, Silvija, Mia i Lucija)

b) Ti imaš istu mitohondrijsku DNA kao tvoji/a... (baka s majčine strane)

c) Darko je nositelj gena za hemofiliju (Xh). Za kojeg člana obitelji možemo s potpunom sigurnošću tvrditi da je nositelj istog gena? (Silvija)

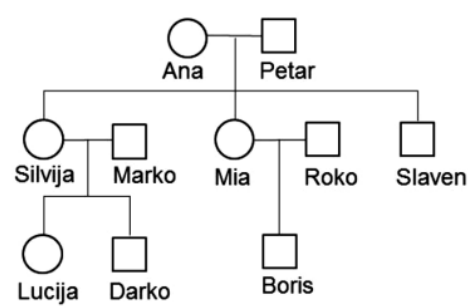

Pitanjem s tri čestice višestrukog izbora (slika 7) provjerava se razumijevanje koncepta oplodnje $i$ nasljeđivanja staničnih organela u kontekstu majčinskog nasljeđivanja mitohondrijske DNA te spolno vezanog nasljeđivanja na primjeru hemofilije (tablica 5). Učenici prema programu ne uče nasljeđivanje mitohondrijske DNA, ali kako je ovo problemski zadatak za učenike na natjecanju za 
njegovo je rješavanje bilo dovoljno osnovno poznavanje koncepta oplodnje kao stapanja jezgara jajne stanice i spermija, uz poznavanje njihove osnovne građe. Da bi točno odgovorili na ovo pitanje, učenici trebaju znati građu jajne stanice i spermija čovjeka te uočiti princip nasljeđivanja organela jajne stanice te svoja znanja primijeniti pri čitanju rodoslovlja i u svakodnevnom životu. Bilo bi puno bolje da se pojam mitohondrijska DNA nije niti spominjao u zadatku, ili da se ponudilo njegovo objašnjenje da sami izraz ne zbuni učenike u primjeni osnovnog znanja koje su savladali tijekom nastave. Uz 5.c pitanje učenici trebaju poznavati oznake dominantnih i recesivnih gena, princip spolno vezanog nasljeđivanja i određivanja spola kod ljudi temeljem kombinacije određenih spolnih kromosoma X i Y te da spolni kromosom Y ne sadrži gen za hemofiliju (tablica 5). Naučeno su učenici trebali primijeniti na prikazano rodoslovno stablo i zaključiti da je Darko gen za hemofiliju mogao naslijediti isključivo od majke (Silvija) jer kao muškarac ima kombinaciju kromosoma XY, a $Y$ kromosom koji ne sadrži gen za hemofiliju mogao je naslijediti isključivo od tate. Zadatak je podijeljen na tri pitanja višestrukog izbora koji provjeravaju navedene koncepte, a svako pitanje je vrjednovano zasebno.

Tablica 4 Karakteristike 5. pitanja na Županijskom natjecanju iz biologije 2015. godine za 8. razred

\begin{tabular}{|c|c|c|}
\hline Tip pitanja & Višestruki izbor & Neophodni koncepti za odgovor učenika \\
\hline Makrokoncept & Razmnožavanje i razvoj organizma & \multirow{3}{*}{$\begin{array}{l}\text { molekula DNA, majčinsko nasljeđivanje, vezani } \\
\text { geni, dominantna i recesivna svojstva, spolni } \\
\text { kromosomi, spolno vezano nasljeđivanje, } \\
\text { određivanje spola, rodbinske veze prikazane u } \\
\text { rodoslovlju }\end{array}$} \\
\hline Koncept & $\begin{array}{l}\text { Nasljeđivanje na razini organizma, Umnožavanje virusa i } \\
\text { ostalih nestaničnih i staničnih tvorbi }\end{array}$ & \\
\hline $\begin{array}{l}\text { Ishodi učenja } \\
\text { (IK DM) }\end{array}$ & $\begin{array}{l}\text { Obrazložiti sposobnost mitohondrija da se umnaža neovisno } \\
\text { o dijeljenju stanice. Analizirati odnose između gena na razini } \\
\text { organizma i nasljednih svojstava. }\end{array}$ & \\
\hline
\end{tabular}

Pitanja uz 5. zadatak provjeravaju sposobnost učenika da analiziraju rodoslovno stablo i zaključe o nasljeđivanju unutar obitelji, primjenjujući i prethodno stečena znanja o oplodnji i staničnim dijelovima. Učenici odgovaraju na pitanje točno s malim varijacijama uz cijeli zadatak u rasponu od $63 \%$ do $66 \%$ (slika 7).

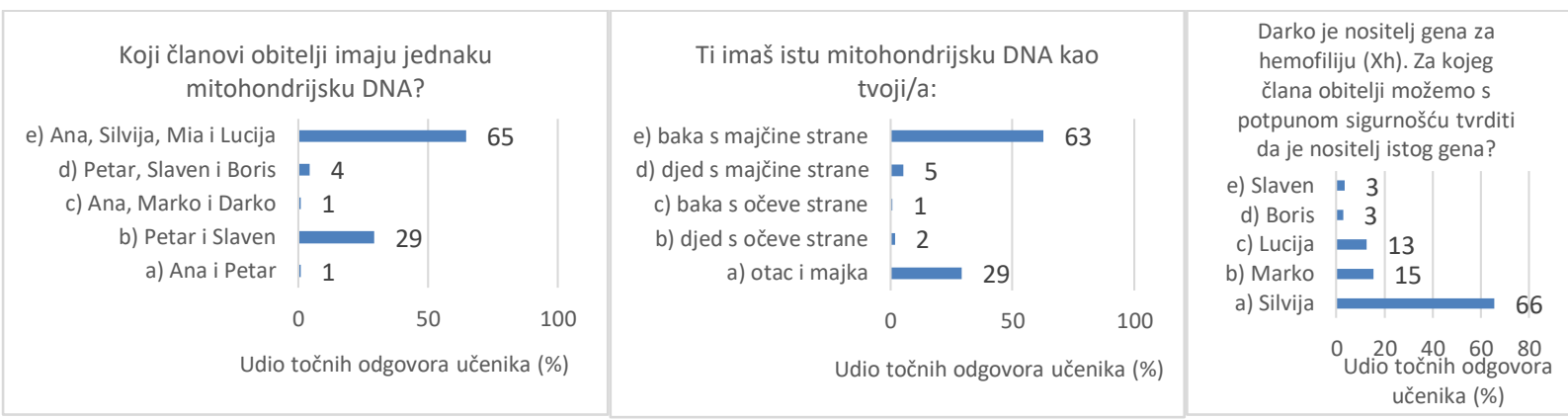

Slika 7 Odgovori učenika na 5. pitanje na Županijskom natjecanju iz biologije 2015. godine za 8. razred

Točan odgovor većine učenika ukazuje da ti učenici dobro određuju srodstvene odnose u prikazu rodoslovlja te ostvaruju bazično razumijevanje procesa oplodnje u kontekstu majčinskog nasljeđivanja mitohondrijske DNA, na osnovu kojeg su mogli zaključiti da se mitohondrijska DNA kod ljudi, ali i kod većine živućih vrsta, nasljeđuje samo po majčinskoj liniji, dok se očeva mitohondrijska DNA odbacuje neposredno prije oplodnje, jer u jajnu stanicu pri oplodnji ulazi samo jezgra spermija.

Netočan odgovor Petar i Slaven uz 5.a pitanje, koji je dalo 29 \% učenika (slika 7) ukazuje na postojanje moguće miskoncepcije da se mitohondrijska DNA nasljeđuje po muškoj liniji, odnosno da se prenosi samo s oca na sina. Moguće je da učenici smatraju da je nasljeđivanje mitohondrijske DNA vezano uz Y kromosom. U ovom slučaju, za provjeravanje konceptualnog razumijevanja nasljeđivanja 
i oplodnje, u uvodni tekst u zadatku može se dodati informacija da neposredno prije stapanja jezgara spermija i jajne stanice, spermij odbacuje svoj mitohondrij. $U$ tom slučaju učenici bi imali dovoljno informacija prema kojima bi mogli uspješno riješiti zadatak ukoliko razumiju proces nasljeđivanja. Za otklanjanje miskoncepcije učenicima se može zadati aktivnost izrade ilustracije, stripa ili modela oplodnje u kojima bi se trebalo jasno prikazati genski materijal u jezgri stanice te mitohondrij $\mathrm{s}$ naglaskom na odbacivanje očinske mitohondrijske DNA neposredno prije oplodnje. Preostali netočni odgovori ukazuju na neispravno čitanje rodoslovnog stabla, odnosno pogrešno tumačenje srodstvenih veza između članova u rodoslovnom stablu. Problem se može otkloniti dodavanjem legende za čitanje rodoslovnog stabla, korištenjem rodoslovnih stabla u nastaviili davanjem zadatka učenicima da izrade rodoslovno stablo svoje obitelji kroz koje će pratiti nasljeđivanje nekih svojstava. Pritom učenici na primjeru uviđaju neka pravila nasljeđivanja lako vidljivih nasljednih svojstava te uče bilježiti srodstvene odnose.

Pitanje 5.b zahtijeva primjenu znanja o nasljeđivanju i oplodnji na primjeru vlastite obitelji učenika, slično kao u zadatku 5.a (slika 7). 29 \% učenika koji su dali odgovor otac i majka pokazuju nepoznavanje procesa oplodnje, jer smatraju da se mitohondrij nasljeđuje od oba roditelja, a možda su i pomiješali su pomiješali mitohondrije i kromosome. 26 \% učenika nije točno odgovorilo na oba pitanja (5.a i 5.b) što ukazuje na nerazumijevanje procesa oplodnje. Učenici koji su odgovorili djed $s$ očeve strane smatraju da se mitohondrij nasljeđuje po očinskoj liniji, a moguće je da smatraju da je nasljeđivanje mitohondrija vezano uz Y kromosom. Ukupno $6 \%$ učenika koji su odgovorili djed $s$ majčine strane i baka s očeve strane ne vežu nasljeđivanje mitohondrija uz jajnu stanicu, ali njihovo tumačenje principa nasljeđivanje mitohondrijske DNA nije jasno iz ovakvih ponuđenih odgovora. Prema odgovorima učenika na pitanja 5.a i 5.b, utvrđeno je konceptualno razumijevanje kod većeg udjela učenika, dok se kod trećine učenika javlja konceptualno nerazumijevanje uzrokovano miskoncepcijama ili problemima u tumačenju srodstvenih odnosa (slika 7).

Pitanje 5.c provjerava sposobnost tumačenja srodstvenih odnosa iz prikaza rodoslovnog stabla neke obitelji te razumijevanje spolno vezanog nasljeđivanja hemofilije. Učenici koji su točno odgovorili na pitanje 5.c (slika 7) pokazuju da znaju točno čitati srodstvene odnose iz prikaza rodoslovlja u zadatku, da znaju protumačiti oznaku Xh kao svojstvo vezano uz X kromosom, da razlikuju X i Y spolni kromosom te da razumiju određivanje spola kod ljudi. Ukupno 66 \% učenika točno je odgovorilo na ovo pitanje. Ti učenici razumiju da je nasljeđivanje gena za hemofiliju vezano uz nasljeđivanje $X$ kromosoma koji muškarci nasljeđuju od majke, što u ovom primjeru znači da jedino majka muškog nositelja sigurno jest roditelj koji nosi isti gen. Učenici koji su dali odgovor Marko (9,73 \%) pokazuju pogrešno razumijevanje spolno vezanog nasljeđivanja i određivanja spola u ljudi (slika 7). Ovaj pogrešan odgovor upućuje na nerazumijevanje određivanja spola u ljudi, tj. nepoznavanje kromosomske garniture muškaraca i žena na reproduktivnoj razini, što uvjetuje nemogućnost primjene znanja na rješavanje primjera. Manji udio učenika dalo je odgovor Lucija (slika 7), što se može povezati s dobrim tumačenjem srodstvenih odnosa u rodoslovnom stablu. Međutim, pokazuje se nerazumijevanje mogućnosti kombinacije i podjele spolnih kromosoma roditelja u gamete, odnosno učenici koji su dali ovaj odgovor smatraju da je nužno da Lucija i Darko od majke naslijede jednaki $X$ kromosom koji nosi hemofiliju. Čak i ovakvom slijedu razmišljanja, susreće se nužnost postojanja Xh kromosoma kod majke Silvije, ili u pogrešnom tumačenju određivanja spola kod oca Marka, pa se može govoriti o nerazumijevanju spolno vezanog nasljeđivanja. Vrlo malen broj učenika koji su odgovorili Boris i Slaven (slika 7) vjerojatno ima problema s čitanjem srodstvenih odnosa u 
rodoslovnom stablu, a pokazuju i potpuno nerazumijevanje spolno vezanog nasljeđivanja i nasljeđivanja općenito, jer jednake gene ne traže u najbližim srodnicima, već u srodnicima koji su udaljeni jedno ili više koljena u rodoslovlju.

Uz pitanje 5 javlja se moguća miskoncepcija da se mitohondrij, a time i mitohondrijska DNA nasljeđuje po muškoj liniji. Navedeno pogrešno razumijevanje ne javlja se podjednako kod učenika svih klasa riješenosti provjere, ali je podjednako zastupljeno kod učenika koji postižu do $60 \%$ riješenosti provjere, dok se smanjuje kod uspješnih učenika (slika 8). Nije utvrđena statistički značajna razlika u pojavi miskoncepcije prema različitim klasama riješenosti $\left(\chi^{2}=2,96 ; d f=7 ; p=1\right)$. Možemo govoriti o postojanju miskoncepcije, jer se ona javlja kod gotovo svih klasa prema riješenosti provjere i potvrđuje u pitanju 5.b, a izostaje samo kod najuspješnijih učenika. Uz pitanje 5.c javlja se pogrešno razumijevanje spolno vezanog nasljeđivanja i određivanja spola u ljudi. Moguća pogreška izostaje kod najuspješnijih učenika koji postižu više od $81 \%$ riješenosti provjere, a zastupljena je kod vrlo malog broja učenika te je proporcionalna slabijoj uspješnosti učenika (slika 8). Nije utvrđena statistički značajna razlika u pojavi miskoncepcije prema različitim klasama riješenosti $\left({ }^{2}=0,98 ; d f=\right.$ $6 ; p=0,96)$. U ovom slučaju, zbog karaktera pitanja koje je tražilo primjenu znanja izborom odgovora, ali bez njegova objašnjenja, ne možemo govoriti o miskoncepciji, već o problemu koji se može riješiti učestalijim vježbanjem na različitim primjerima.
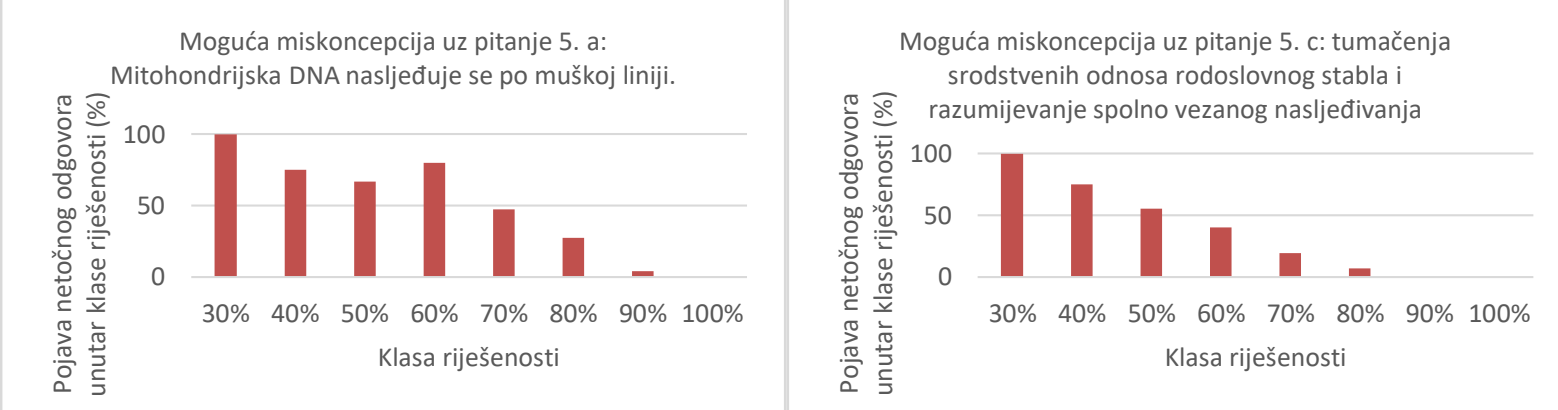

Slika 8 Udio učenika kod kojih se pojavljuje moguća miskoncepcija uz pitanje 5. a i c prema klasama riješenosti provjere

Pitanje 7. Osobe s Klinefelterovim sindromom imaju tri spolna kromosoma, XXY, pa je ukupan broj njihovih kromosoma 47. Kako mogu nastati takve jedinke?

a) do greške je došlo jer je spermij s XY kromosomima oplodio jajnu stanicu $(T)$

b) do greške je došlo u I. mejotičkoj diobi u jajniku majke (T)

c) dva su spermija, jedan $s X$, a jedan s $Y$, oplodila jajnu stanicu

d) nisu se razdvojile kromatide $X$ kromosoma u II. mejotičkoj diobi prilikom nastanka spermija

e) X kromosom se udvostručio prilikom ulaska zigote u mitozu, ali se nije podijelio.

Pitanje bi trebalo provjeriti konceptualno razumijevanje nasljeđivanja na razini organizma i životni ciklus stanice (tablica 6). Da bi točno odgovorili na pitanje, učenici moraju primijeniti znanja o promjeni strukture i broja kromosoma u stanici tijekom mejoze i procesu oplodnje, poznavati određivanje spola u ljudi te prepoznati koji spolni kromosom se nasljeđuje od majke, a koji od oca.

Tablica 5 Karakteristike 7. pitanja na Županijskom natjecanju 2015. godine za 8. razred

\begin{tabular}{|c|c|c|}
\hline Tip pitanja & Višestruke kombinacije & Neophodni koncepti za odgovor učenika \\
\hline Makrokoncept & Razmnožavanje i razvoj organizma & \multirow{3}{*}{$\begin{array}{l}\text { spolni kromosomi, određivanje spola, spolni } \\
\text { kromosomi u spolnim stanicama, mitoza i } \\
\text { mejoza, oplodnja, stalnost broja kromosoma } \\
\text { vrste }\end{array}$} \\
\hline Koncept & Nasljeđivanje na razini organizma, Životni ciklus stanice & \\
\hline $\begin{array}{l}\text { Ishodi učenja (IK } \\
\text { DM) }\end{array}$ & $\begin{array}{l}\text { Identificirati uzroke mutacija i moguće posljedice na razini } \\
\text { jedinke/populacije/vrste. Analizirati životni ciklus stanice. }\end{array}$ & \\
\hline
\end{tabular}


Učenici koji su dali potpuno točan odgovor (29 \%) pokazuju razumijevanje određivanja spola kod ljudi te pokazuju konceptualno razumijevanje procesa mejoze pri nastanku spolnih stanica. Odabrani odgovori ukazuju na to da učenici razumiju promjene broja i strukture kromosoma u stanici tijekom mejoze i ulogu tih zbivanja za održavanje stalnosti broja kromosoma neke vrste. Točni odgovori pokazuju točno razumijevanje uzroka greške u broju spolnih kromosoma. U oba slučaja radi se o nerazdvajanju spolnih kromosoma u I. mejotičkoj diobi, što uzrokuje daljnje zajedničko nasljeđivanje oba kromosoma. U oplodnji u kojoj sudjeluje stanica s dva spolna kromosoma nastaje potomak $s$ tri spolna kromosoma u stanicama, odnosno ukupno 47 kromosoma u stanici. Učenici koji su dali odgovor opisan kao "djelomično razumijevanje A", točno su odgovorili da se uzrok može tražiti u spermiju $s$ dva spolna kromosoma, X i $Y$, koji se tijekom oplodnje spaja $s$ jajnom stanicom $s$ normalnim brojem kromosoma, ali su drugi mogući uzrok nastanka osobe $s$ tri spolna kromosoma tražili u pogrešnom dijelu životnog ciklusa stanice. Učenici koji su dali odgovor opisan kao "djelomično razumijevanje B" dali su točan odgovor da do greške dolazi tijekom I. mejotičke diobe pri nastajanju jajne stanice, ali drugi uzrok traže u oplodnji jedne jajne stanice s dva spermija ili smatraju da se greške događaju u pogrešnom dijelu životnog ciklusa stanice.

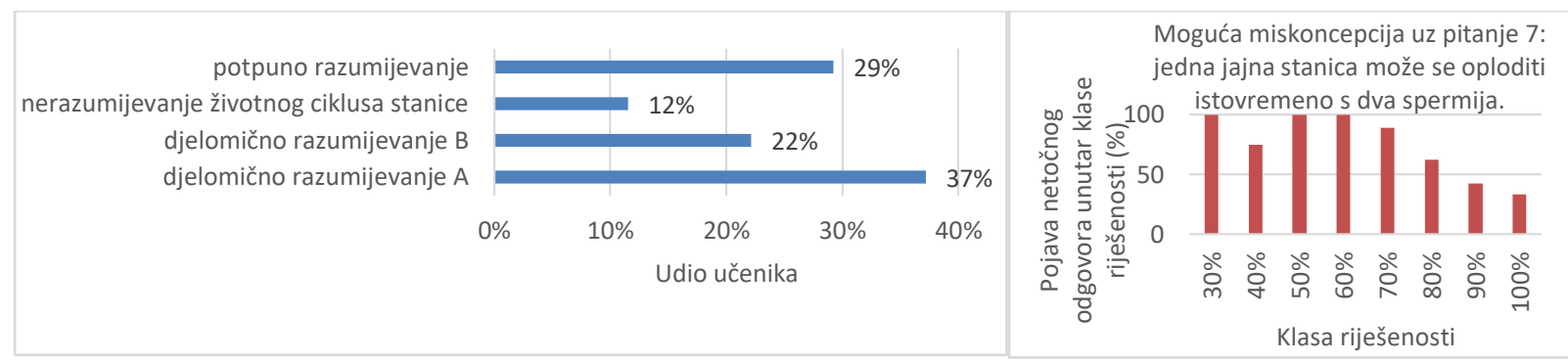

Slika 9 Značenje odgovora učenika na 7. pitanje natjecanja 2015. godine za 8. razred i njihova raspodjela prema klasama riješenosti

U samoj formulaciji pitanja 7 kao i ponuđenih odgovora postoji problem, jer se računalo samo na informacije koje učenici mogu naći u udžbenicima, dok postoji još mogućih točnih odgovora poput odgovara da se jedna jajna stanica može oploditi istovremeno s dva spermija. Tako ovo pitanje ne može sa sigurnošću utvrditi stvarne probleme učenika, već ukazuje na to da su možda pitanja vezana za sindrome prezahtjevna za osnovnu školu. Svakako je neophodno jasno opisati kontekst zadatka kako bi se izbjegle mogućnosti iznimaka u odgovorima, a koje mogu biti točan odgovor, jer uvijek postoji mogućnost da su možda neki učenici iskazali veliki interes za tu temu i saznali mnogo više od činjenica predviđenih nastavnim programom. Taj se odgovor u većoj mjeri pojavljuje kod učenika $s$ manje od $61 \%$ riješenosti provjere (slika 9) te se za te odgovore može pretpostaviti da je to miskoncepcija. Takav odgovor je prisutan i kod 9,73 \% najuspješnijih učenika (slika 9), a takav rezultat upravo ukazuje na mogućnost da su ti učenici primijenili informacije šire od onih opisanih u udžbeniku, ali se to na osnovu ovakvog pitanja ne može u potpunosti tvrditi te je moguće postojanje miskoncepcije i kod ovih učenika. lako je to iznimka ipak je moguće, kao što su to zaključili i neki učenici te kao točan odgovor biraju da su dva spermija, jedan $s X$, a jedan $s Y$, oplodila jajnu stanicu. Nije utvrđena statistički značajna razlika u pojavi ovog odgovora prema različitim klasama riješenosti $\left(\chi^{2}=0,74 ; d f=7 ; p=0,99\right)$. Bolje razumijevanje ovog koncepta bilo bi moguće postići korištenjem izrade modela životnog ciklusa stanice, oplodnje i razvoja zametka iz zigote, posebno obraćajući pažnju na vrste i broj kromosoma koji u tim procesima sudjeluju. Aktivnost bi se mogla izvršiti tako da se učenici podijele u više grupa od kojih će svaka modelirati drugačiju promjenu u broju kromosoma, npr. Klinefelterov sindrom, Downov sindrom, itd. pazeći da grešku naprave namjerno u pravom dijelu 
životnog ciklusa stanice, te da naglase da se tijekom dijeljenja zigote i razvoja u zametak stanice ne mijenjaju, već nastaju njihove identične kopije. Uz to je jasno da je potrebno pažljivije razmotriti sve ponuđene distraktore u pitanjima.

Pitanje 13. Na slici je prikazan homologni (istovjetni) par kromosoma s genima za određena svojstva označena slovima $A, B$, $D, E, F$. Stanica s prikazanim kromosomskim parom nalazi se $u$ sjemeniku i ulazi u mejotsku diobu.

a) Koja bi se dva kromosoma, od predloženih pet, mogla naći u spermijima koji su nastali mejozom početnog homolognog para? (3.
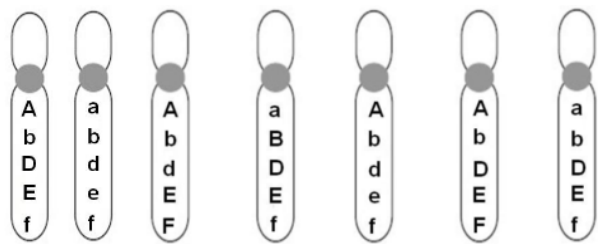
i 5.)

1. $2 . \quad 3 . \quad 4.4$. 5 .

b) Obrazloži kako dolazi do prikazanih promjena i u kojem dijelu mejoze se mogu dogoditi. Kakav je njihov značaj za spolno razmnožavanje i raznolikost unutar vrste?

Očekivani odgovor:

- homologni/istovjetni kromosomi se sparuju i pritom mogu izmijeniti dijelove kromatida/ cossingover (0,5 boda); tijekom prvog dijela diobe/mejoza I./I. mejotička dioba (0,5 boda);

- nastaju spermiji koji su međusobno genski različiti što pridonosi genetskoj raznolikosti jedinki nastalih spolnim razmnožavanjem (1 bod), ukoliko se navodi samo povećanje raznolikosti (0,5 boda).

Dvoslojnim pitanjem uz vezanje potpitanja a) i b) provjerava se konceptualno razumijevanje promjene broja i strukture kromosoma tijekom mejoze. Da bi uspješno riješili zadatak, učenici trebaju primijeniti prethodno usvojena znanja o procesu mejoze, odnosno analizirati promjene na kromosomima koje se događaju u pojedinoj fazi mejoze $i$ objasniti ih na konkretnom primjeru. Učenici se trebaju prisjetiti utjecaja spolnog razmnožavanja na gensku raznolikost neke vrste te prepoznati moguće promjene na genima unutar jedne stanice (tablica 7).

Tablica 6 . Karakteristike 13. pitanja na Županijskom natjecanju 2015. za 8. razred

\begin{tabular}{|l|l|l|}
\hline Tip pitanja & Višestruki izbor, otvoreni tip & Neophodni koncepti za odgovor učenika \\
\hline Makrokoncept & Razmnožavanje i razvoj organizma & DNA, kromosom, kromatidna izmjena ili crossing- \\
Koncept & Nasljeđivanje na razini organizma, Životni ciklus stanice & $\begin{array}{l}\text { over, mejoza, bioraznolikost, genska raznolikost, } \\
\text { spolno razmnožavanje }\end{array}$ \\
\cline { 1 - 2 } $\begin{array}{l}\text { Ishodi učenja } \\
\text { (IK DM) }\end{array}$ & $\begin{array}{l}\text { Analizirati odnose među genima i njihov utjecaj na razini } \\
\text { organizma ili nasljedne osobine. Analizirati životni ciklus } \\
\text { stanice. }\end{array}$ & \\
\hline
\end{tabular}

Većina učenika ovaj je zadatak riješila netočno ili djelomično točno (slika 10). U 13.a pitanju, učenici su trebali usporediti ponuđene odgovore i prepoznati točne na temelju označenih varijanti gena u homolognom paru kromosoma s početka mejoze. Zadatak je uspješno riješilo 85 \% učenika. Ostatak učenika odabirao je odgovore u kojima se pojavljuju varijante gena koje nisu bile prisutne $u$ početnom homolognom paru kromosoma (slika 10), što znači da učenici smatraju da se tijekom mejoze u stanici mogu pojaviti nove varijante gena koje u tom organizmu prije nisu postojale. Takvi odgovori ukazuju na moguće postojanje miskoncepcije, koja se javlja kod $15 \%$ učenika (slika 10). 13.b pitanje otvorenog tipa od učenika je zahtijevalo obrazloženje prikazane promjene kromosoma i značaja spolnog razmnožavanja za raznolikost vrste. Učenicima je potpuno točan odgovor vrjednovan ako je bio sadržajno ekvivalentan sljedećem: "Homologni kromosomi se sparuju i pritom mogu izmijeniti dijelove kromatida. To se naziva crossing over. Odvija se tijekom prvog dijela mejoze. Nastaju spermiji koji su međusobno genski različiti, što pridonosi raznolikosti jedinki nastalih spolnim razmnožavanjem." Učenički odgovori specifično su kodirani i podijeljeni u skupine prema njihovom značenju za razumijevanje ispitivanog koncepta (slika 10). Samo $12 \%$ učenika ponudilo je potpuno točan odgovor na pitanje, dok je većina učenika točno objasnila utjecaj crossing-overa na spolno razmnožavanje i raznolikost vrste, a pogrešno odredila dio životnog ciklusa stanice u mejozi tijekom kojeg se prikazane promjene na genima događaju. Učenici razumiju važnost spolnog razmnožavanja i 
izmjene gena za raznolikost unutar vrste, ali nedostaju im znanja na reproduktivnoj razini koja nisu dio obaveznog programa Biologije u osnovnoj školi, što je bio razlog za izostanak točnog odgovora kod većine učenika. Važno je da nastavnici spomenu da kromosomi mogu izmijeniti dijelove, a time i gene i da je to povezano s raznolikošću, ali nikako ne treba inzistirati da u toj dobi znaju kada se to točno dogodi. Zadatak bi bio puno kvalitetniji da je ponuđena slika koja pruža osnovu za rješavanje zadatka s bazičnim znanjem na razini osnovne škole.

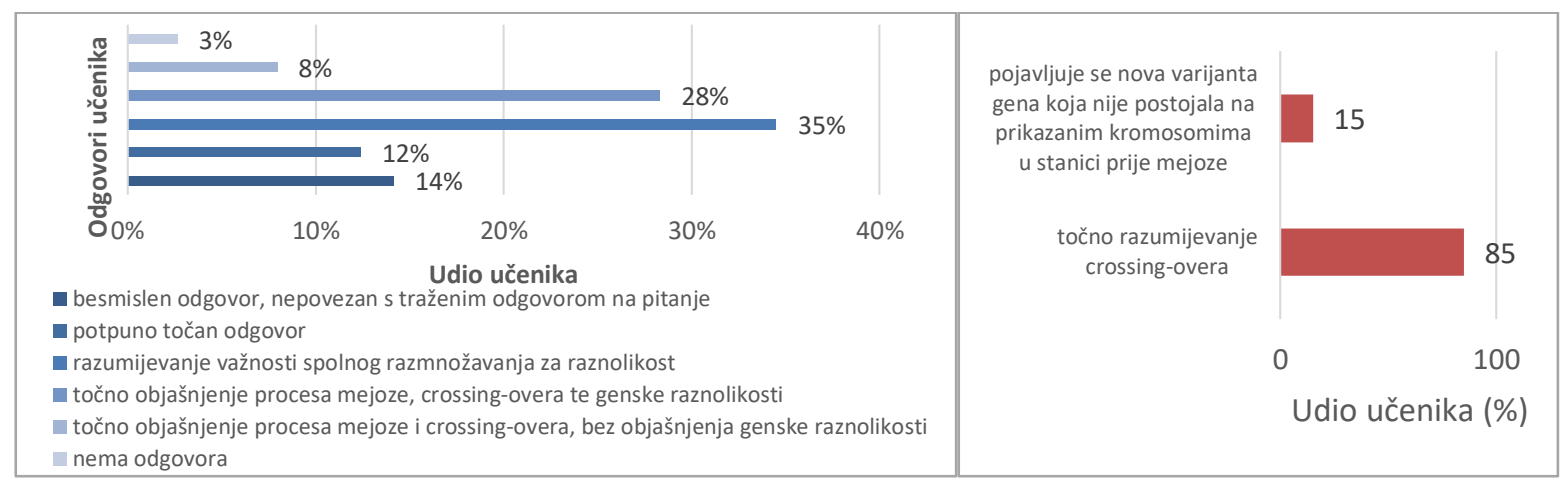

Slika 10 Odgovori učenika na 13. pitanje provjere 2015. za 8. razred

Ako se uzmu u obzir odgovori učenika na oba dijela 13. zadatka, konceptualno razumijevanje promjene strukture kromosoma, odnosno izmjene gena tijekom mejoze ima $12 \%$ učenika. $U$ toj su skupini učenici koji su ponudili potpuno točan odgovor na oba dijela zadatka, te oni koji su se nepotpuno izrazili, ali su pokazali točno razmišljanje u dijelu zadatka 13.b. Razinu prepoznavanja ostvarili su učenici koji su točno riješili samo 13.a. zadatak, a razinu primjene oni koji su točno riješili pitanje 13.a te obrazložili prikazane promjene. Djelomično konceptualno razumijevanje ostvarili su učenici koji su obrazložili prikazane izmjene, no nisu spomenuli spolno razmnožavanje, dok su gensku raznolikost vrste dobro objasnili. Problemi koji uzrokuju netočne odgovore učenika mogu se pronaći u memoriranju, kada učenici nemaju reproduktivno znanje da se crossing over odvija u prvoj mejotičkoj diobi, a problemi mogu nastati i tijekom učenja i poučavanja. $U$ tom slučaju učenici nisu usvojili utjecaj spolnog i nespolnog razmnožavanja na gensku raznolikost vrste. Učenicima se mogla ponuditi slika koja prikazuje mejozu te od njih tražiti da prepoznaju crossing-over i mejotičku diobu u kojoj se on zbiva. Konceptualnom razumijevanju pridonijelo bi da učenici tijekom nastave dobiju zadatak da koristeći se multimedijskim izvorima (znanstveni časopisi, internet,...) odaberu slike i videozapise populacija genski identičnih jedinki te populacija genski različitih jedinki, s time da populacije ne moraju pripadati istoj vrsti. Učenici bi na temelju pronađenih materijala trebali usporediti izgled, veličinu, ponašanje, stanište i slične lako uočljive karakteristike te ih usporediti, navesti i obrazložiti njihove prednosti i ograničenja. Tako bi učenici na primjeru mogli usvojiti važnost genske raznolikosti unutar vrste.

Uz pitanje 13 javlja se moguća miskoncepcija da se tijekom mejoze na kromosomima mogu pojaviti varijante gena koje nisu postojale na homolognom paru kromosoma s početka mejoze. Moguća miskoncepcija na razini odabira odgovora pod 13.a pojavljuje se u omjerima koji su razmjerni klasama riješenosti (slika 11), a preko $40 \%$ kod učenika koji su ostvarili manje od $60 \%$ riješenosti provjere. Za razliku od toga kod pitanja 13.b gdje se traži objašnjenje odgovora uočljivo je da se unutar klasa netočni odgovori javljaju u frekvencijama većim od 70 \% izuzev najuspješnijih učenika (slika 11). Nije utvrđena statistički značajna razlika u pojavi miskoncepcije prema različitim klasama 
riješenosti $\left(\chi^{2}=0,86 ; d f=7 ; p=0,97\right)$. U ovom slučaju možemo govoriti o postojanju miskoncepcije, a posebno izražene kod učenika koji pripadaju nižim klasama riješenosti (slika 11).

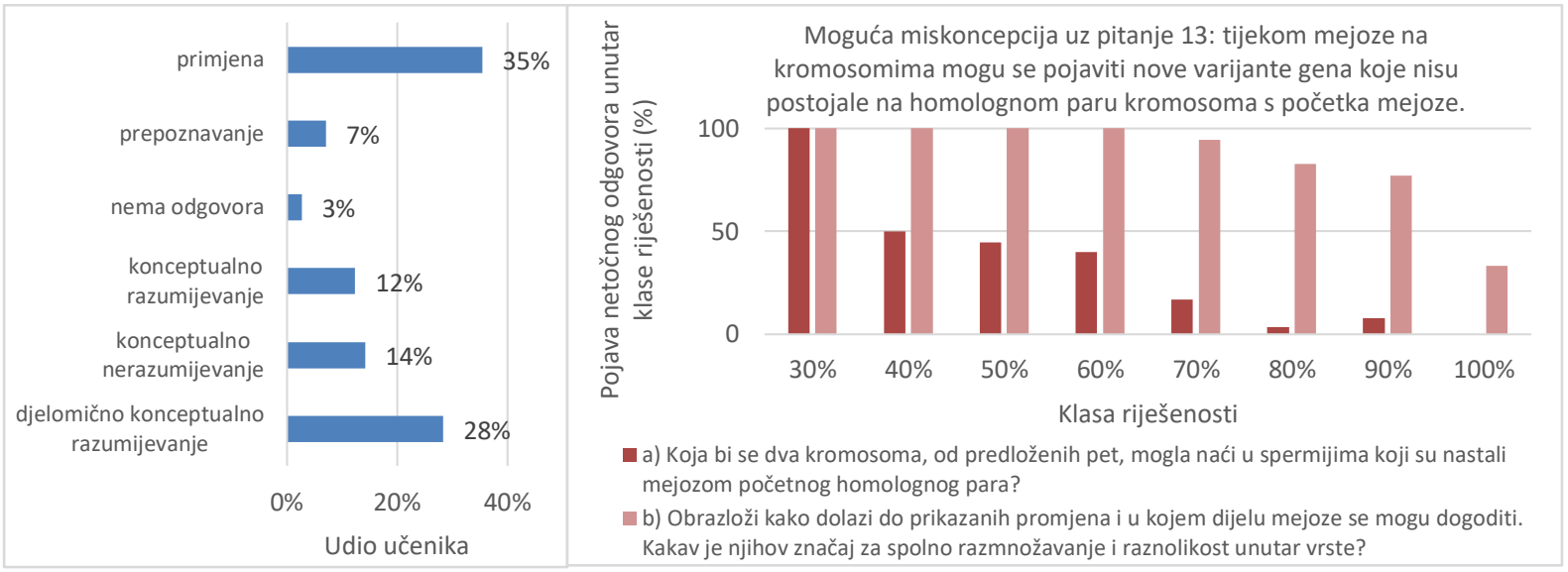

Slika 11 Analiza razine razumijevanja koncepta izmjene gena tijekom mejoze

\section{RASPRAVA}

Većinu izdvojenih pitanja učenici su rješavali primjenom znanja, a manji udio pitanja reprodukcijom znanja. Uz makrokoncept Razmnožavanje i razvoj organizma nije postojao niti jedan zadatak treće kognitivne razine. Svako izdvojeno pitanje provjeravalo je jedan koncept, odnosno makrokoncept kod složenijih pitanja, što je u skladu s preporukama za autore pitanja za natjecanje (Radanović i sur., 2013). Zastupljenost ključnih koncepata unutar makrokoncepta razmnožavanje na županijskom natjecanju odgovara zastupljenosti istih koncepata u nastavnom sadržaju, te su pitanja usklađena za provjeru ishoda predviđenih Nacionalnim planom i programom za osnovnu školu (MZOŠ, 2006), a s obzirom da su to bitni ishodi za poznavanje biološke osnove, slični ishodi istaknuti su i u ispitnom katalogu državne mature (Radanović i sur, 2015). Rezultati podupiru zaključak Begić i sur. (2016) da je vidljiva potreba za promjenom nastavnog programa zbog neuravnotežene zastupljenosti makrokoncepata u nastavnim sadržajima biologije i njihovog odraza na konceptualno učenje. Osim toga neophodno je omogućiti povezivanje između bioloških disciplina koje podržavaju nastavne teme, da bi se osigurala konceptualna nadogradnja i sistematizacija konceptualnog razumijevanja.

Analizom svakog učeničkog odgovora na pojedino pitanje bilo je moguće utvrditi biološko značenje odgovora te izdvojiti pogrešne odgovore koji se učestalo ponavljaju ili imaju isto značenje u razumijevanju ispitivanog koncepta. Odgovori na pitanja dali su uvid u pogrešna razmišljanja koja se često javljaju kod izvrsnih učenika koji sudjeluju na županijskom natjecanju iz biologije.

Na stručnim vijećima nastavnika biologije, nastavnici su izdvojili očekivane miskoncepcije s kojima se kod učenika susreću na kraju osnovnoškolskog obrazovanja (Lukša i sur, 2013). Pri tom su nastavnici izdvojili sljedeće miskoncepcije: "ne razlikuju mitozu i mejozu"; "ne razlikuju broj kromosoma u tjelesnim i spolnim stanicama"; "ne povezuju mitozu i mejozu s tjelesnim i spolnim stanicama", što će se koristiti kao osnova za usporedbu s rezultatima ovog istraživanja.

Pitanja u županijskom natjecanju iz biologije za sedmi razred 2015. i 2017. godine većim su udjelom provjeravala ključni koncept životnog ciklusa stanice, te su se prema odgovorima učenika izdvojila pogrešna razmišljanja koja odgovaraju navedenim očekivanim miskoncepcijama. Međutim, uzevši u obzir uspjeh učenika i razinu razumijevanja koncepta, ne može se govoriti o pojavi miskoncepcije "ne razlikuju mitozu i mejozu", jer takva izjava nije dovoljno precizna u definiranju miskoncepcije, a 
prema rezultatima učenika utvrđeno je da se radi o neznanju učenika slabijeg uspjeha. Kod očekivane miskoncepcije "ne razlikuju broj kromosoma u tjelesnim i spolnim stanicama", na uzorku učenika sudionika natjecanja 2017. godine utvrđena je izrečena očekivana miskoncepcija na primjeru tjelesnih i spolnih stanica pčela. Kod učenika s natjecanja 2015. godine isti se koncept ispitivao kroz drugi tip zadatka te nije određeno postojanje miskoncepcije, nego nedostatak znanja na I. i II. kognitivnoj razini. Velik broj učenika koji je na spomenuto pitanje odgovorilo netočno pripada u VII. klasu riješenosti provjere, što odgovara rezultatima Garašić (2012), prema kojima je prosječna usvojenost bioloških znanja učenika u Hrvatskoj ispod $50 \%$, s time da je najveća prosječna usvojenost sadržaja na I. kognitivnoj razini, a opada prema III. kognitivnoj razini. Očekivana miskoncepcija "ne povezuju mitozu i mejozu s tjelesnim i spolnim stanicama" nije utvrđena na uzorku učenika u ovom istraživanju. Povezani koncept ispitivan je kroz jednu tvrdnju u zadatku alternativnog izbora gdje je čak $90 \%$ učenika odgovorilo točno.

Ukupno, možemo govoriti o slaganju dobivenih rezultata s ranijim istraživanjima, u kojim se najviše problema uz makrokoncept Razmnožavanje i razvoj organizma odnosi upravo na životni ciklus stanice (Lukša i sur, 2016), a ponajviše na proces mejoze, konkretno važnost promjene broja kromosoma u stanici kroz mejozu. S obzirom da se stanične diobe ponavljaju kroz nastavni sadržaj biologije u osnovnoj i srednjoj školi, a učenici i na kraju srednjoškolskog obrazovanja imaju jednake probleme u razumijevanju životnog ciklusa stanice kao i učenici u osnovnim školama, uzroke možemo potražiti u tradicionalnom načinu poučavanja staničnih dioba koji često uključuje predetaljne opise procesa (Lukša, 2011; Lukša i sur, 2016). Isti problem javlja se i u slučajevima kada nastavnici inzistiraju na nazivlju pojedinih faza mitoze i mejoze bez razumijevanja događaja tijekom samih procesa, koji su učenicima apstraktni (Radanović i sur, 2017 a). Kao što ističe Garašić (2012), kod nekih pitanja koja ispituju uloge staničnih dioba lako je moguće da netočan odgovor nije rezultat nerazumijevanja, već zamjene naziva staničnih dioba, koje učenici često nazivom miješaju i lako zaboravljaju. Zbog toga, nastava biologije trebala bi se mijenjati tako da se poučavanje i provjeravanje postignuća ne temelji na nazivlju kojim ne možemo provjeriti znanje na razini razumijevanja, kao što je bio slučaj u dijelovima pitanja 22 (2015. godine, 7. razred), te pitanja 13 (2015. godine, 8. razred), gdje se točnost odgovora oslanja na prisjećanje naziva određene vrste stanične diobe.

Kod dijela učenika 8. razreda koji su bili sudionici natjecanja 2015. godine uočeno je pogrešno mišljenje da su svi kromosomi u tjelesnim stanicama tjelesni kromosomi, koje se prema istraživanju Garašić (2012) ponovno javlja u uzrastu učenika 3. i 4. razreda gimnazije. U spomenutom se istraživanju ovo pogrešno razmišljanje nadopunjuje odgovorima učenika prema kojima u spolnim stanicama možemo pronaći samo spolne kromosome. $U$ istom se istraživanju kod učenika 4. razreda gimnazije javljaju problemi pri povezivanju broja molekula DNA u tjelesnim i spolnim stanicama čovjeka, a koji se pojavljuju i kod učenika osmog razreda 2015. godine. S obzirom da se spomenuti koncepti spominju više puta kroz nastavu biologije u osnovnoj i srednjoj školi kao sastavni dio nastavnih sadržaja biologije za sedmi i osmi razred, te za prvi i četvrti razred gimnazije, valjalo bi provjeriti njihovo razumijevanje kod iste generacije učenika više puta tijekom školovanja. Nerazumijevanje veze kromosoma, kromatida, molekule DNA i gena česta je miskoncepcija kod učenika svih uzrasta (Berthelsen, 1999), a loši rezultati kod učenika hrvatskih škola potvrđuju se i u istraživanju Lukše i sur. (2016). Uspješni učenici biti će uspješni bez obzira kakvu podršku dobivaju od nastavnika, što potvrđuju rezultati Lugar i Mustać (2016) koji ukazuju da najuspješniji učenici na 
natjecanju uspješnije rješavaju zadatke viših kognitivnih razina što je posljedica konceptualnog razumijevanja nastavnih sadržaja te razumijevanja i primjene uzročno-posljedičnih veza. Konceptualno razumijevanje omogućit će im i olakšati donošenje vlastitih ili razumijevanje tuđih odluka kao odgovornih osoba i članova društva (Lukša i sur, 2013).

Većina učenika sudionika županijskog natjecanja za osmi razred pokazuje dobro poznavanje broja kromosoma u stanicama nakon mitoze i mejoze. $U$ nacionalnim ispitima provedenima 2008. godine, samo je petina učenika ponudila točne odgovore na više pitanja koja su provjeravala taj koncept (Radanović i sur, 2010). S obzirom da su se u izradi ovog rada analizirali odgovori $20 \%$ najuspješnijih učenika na Županijskom natjecanju, a isti su učenici u većem dijelu pokazali razumijevanje promjene broja kromosoma kroz stanični ciklus, može se govoriti da se rezultati slažu i ne postoji velika razlika u razumijevanju broja i strukture kromosoma u stanici kroz generacije.

Dio učenika osmog razreda koji su sudjelovali na Županijskom natjecanju 2015. godine pokazuje loše razumijevanje procesa oplodnje, što se provjeravalo kroz nekoliko pitanja na provjeri. U dosadašnjim istraživanjima nisu izdvojena pitanja koja bi se vezala uz koncept oplodnje te stoga nisu uočeni problemi u razumijevanju, ali s obzirom da se radi o odgovorima $20 \%$ najuspješnijih učenika na Županijskom natjecanju, valjalo bi provjeriti kakvo je razumijevanje procesa oplodnje kod čitave generacije učenika osmog razreda.

Na Županijskom natjecanju za sedmi razred 2015. godine pitanja uz makrokoncept Razmnožavanje i razvoj organizma bila su različitih tipova - dva zadatka višestrukog izbora, te po jedan zadatak navođenja iz crteža i zadatak redanja. Na Županijskom natjecanju 2017. sva su pitanja vezana uz koncept razmnožavanje bila zadaci alternativnog izbora s po pet konceptualno povezanih tvrdnji. Učenici na natjecanju 2015. godine bili su uspješniji pri rješavanju pitanja višestrukog izbora, iako ponuđeni distraktori nisu bili međusobno konceptualno povezani. Kod zadataka alternativnog izbora, pojedinačne tvrdnje u zadatku uglavnom su vrlo uspješno rješavane, međutim ukupna riješenost zadatka odstupa od tih rezultata, prema čemu se može zaključiti da određen udio točnih odgovora na pojedinu tvrdnju proizlazi iz pogađanja odgovora te da učenici slabo povezuju tvrdnje unutar istog pitanja da bi logički došli do točnog odgovora.

Makrokoncept Razmnožavanje i razvoj organizma na županijskim natjecanjima u najvećem je udjelu zastupljen pitanjima II. kognitivne razine, odnosno razine primjene i konceptualnog razumijevanja. Uspješno rješavanje tih pitanja cilj je koji se želi ostvariti kod što većeg broja učenika biologije. Pri rješavanju složenih zadataka, učenici uglavnom pokazuju djelomično konceptualno razumijevanje. Uzrok tome može se potražiti u načinu učenja i poučavanja biologije koji još uvijek vlada hrvatskim školama, a koji zahtijeva veliku količinu reproduktivnog znanja koje se tek djelomično sustavno izgrađuje i usložnjava na višu kognitivnu razinu. Učenici nisu navikli da se od njih traži primjena znanja, već ih se obično provjerava zadacima prve kognitivne razine gdje često mogu dati odgovor na temelju prepoznavanja ili memoriranja činjenica. Na županijskim natjecanjima, međutim, preporučen je omjer zadataka otprilike 1/5 zadataka I. kognitivne razine, 2/3 zadataka II. kognitivne razine i 1/3 zadataka III. kognitivne razine (Radanović i sur, 2013). U sve tri provjere najbolje su rješavani zadaci I. kognitivne razine, bez obzira na težinu, dok riješenost zadataka pada kod zadataka više kognitivne razine (Begić i sur, 2016; Lugar i Mustać, 2016). U ovom radu pokazalo se da na županijskom natjecanju ipak dolaze i pitanja I. kognitivne razine, što bi se trebalo izbjegavati, budući se radi o učenicima koji su vrlo uspješni i ostvaruju iznadprosječne rezultate u nastavi biologije. Međutim, 
kombinacija pitanja I. razine koja provjerava ključne činjenice može se uključiti u zadatke viših kognitivnih razina, kao u pitanju 22 na natjecanju 2015. godine. Izdvojena pitanja sa Županijskog natjecanja iz biologije za 8. razred bila su vezana uz koncept nasljeđivanja na razini organizma $\mathrm{i}$ stanice te uz razmnožavanje čovjeka. Od izdvojenih pitanja, niti jedno nije bilo III. kognitivne razine.

Nastavni programi prirode i biologije u hrvatskim školama sadržajno su orijentirani, a sadržaji su vezani uz podjelu biologije prema područjima (Lukša i sur., 2013, prema Radanović i sur., 2017 c). Slično se može vidjeti i u organizaciji nastave biologije u drugim zemljama, gdje se biologija uči na osnovu pamćenja činjenica bez njihova međusobnog povezivanja (Din Yan Yip, 1998). Tek se unatrag nekoliko godina može pronaći reorganizacija nastavnih sadržaja biologije prema konceptima, npr. u ispitnom katalogu državne mature, gdje se obrazovni ishodi organiziraju prema konceptima koje ispituju te se na taj način tvore konceptualne poveznice između nastavnih tema obuhvaćenih nastavnim planom i programom za biologiju. U samom načinu učenja i poučavanja biologije, nalazimo probleme jer hrvatski nastavnici nemaju dovoljan uvid u stvarno konceptualno razumijevanje učenika (Lukša, 2011), pa ne mogu ispravno odrediti predkoncepcije i očekivane miskoncepcije, čije bi poznavanje bilo vrlo korisno u planiranju nastave.

Konceptualne mape koristan su alat čijom se primjenom u nastavi kod učenika pospješuje retencija znanja, ali i bolji rezultati u rješavanju pitanja viših kognitivnih razina (Latin i sur, 2016). Učenici koji u nastavi koriste konceptualne mape samostalno uče, povezuju pojmove i kritički razmišljaju, što pridonosi njihovom kasnijem uspjehu pri rješavanju zadataka viših kognitivnih razina (Latin i sur, 2016; Adamov i sur, 2009; Yip, 1998), dok su učenici koji tijekom učenja izrađuju konceptualne mape uspješniji u prepoznavanju veza između koncepata (Radanović i sur, 2017). S obzirom da su brojni problemi uočeni tijekom ove analize posljedica slabijeg konceptualnog povezivanja učenika, potrebno je u budućim istraživanjima utvrditi mogućnost savladavanja uočenih problema uz pravilnu primjenu konceptualnih mapa kao alata za sistematizaciju znanja učenika.

\section{ZAKLJUČAK}

Učenici bolje rješavaju zadatke niže kognitivne razine te zadatke u kojima za točan odgovor nije potrebno konceptualno razumijevanje. Učenici bolje rješavaju zadatke više kognitivne razine ako je za dio zadatka dostatna reprodukcija znanja ili se u zadatku eliminacijom netočnih odgovora i logičnim zaključivanjem može odrediti točan odgovor, što ukazuje na to da se u nastavi kod učenika često ne traži i ne provjerava znanje na višim kognitivnim razinama, iako je znanje na razini razumijevanja važno svim učenicima, a ne samo onima najuspješnijima.

Utvrđeno je postojanje nekoliko miskoncepcija, usko vezanih uz ključni koncept životni ciklus stanice. Najviše poteškoća učenici imaju u razumijevanju uloge mitoze i mejoze u rastu, razvoju i razmnožavanju organizma. Učenici imaju poteškoća u povezivanju temeljnog koncepta životnog ciklusa stanice s drugim temeljnim konceptima unutar makrokoncepta Razmnožavanje i razvoj organizma.

Veći udio netočnih odgovora na pitanja uz makrokoncept Razmnožavanje i razvoj organizma proizlazi iz nedostatnog znanja, lošeg povezivanja znanja te krivog tumačenja zadatka, a ne miskoncepcija, što je povezano s problemima u učenju i poučavanju, odnosno prevladavajućem tradicionalnom obliku nastave u hrvatskim školama. 
Učenici osmog razreda pokazuju loše razumijevanje koncepta oplodnje te povezanosti kromosoma i molekula DNA u stanici, što potvrđuje rezultate ranijih istraživanja. Loši rezultati povezani su s površnim spominjanjem navedenih koncepata tijekom učenja i poučavanja biologije, pretežito tradicionalnim oblikom nastave te ukazuju na potrebu promjene u kreiranju nastave biologije i primjene novih nastavnih strategija koje će se oslanjati na samostalni rad učenika.

Rezultati analize pitanja i odgovora učenika važno je uočiti da kod pitanja višestrukog izbora ne možemo isključiti mogućnost pogađanja odgovora, kao ni mogućnost da su učenici za točan odgovor iskoristili djelomično memorirane činjenice bez dubljeg razumijevanja. Osim toga sam izbor pojedinog distraktora nije dovoljan da s potpunom sigurnošću utvrdimo postojanje miskoncepcija. Za potvrdu utvrđenih miskoncepcija u ovom radu bilo bi potrebno u sljedećoj fazi iste ispitati korištenjem pitanja otvorenog tipa, dvoslojnim pitanjima ili intervjuiranjem učenika. Jednako tako potrebno je u utvrđenim problematičnim konceptima analizirati udžbenike kao moguće izvore miskoncepcija jer su primjerice mitoza i mejoza dosta problematično opisane u nekim udžbenicima. Moguće je da i kod dijela nastavnika postoje određene miskoncepcije kojih oni nisu svjesni, a koje onda prenose svojim učenicima. Ovu tvrdnju svakako bi trebalo ispitati u sljedećoj fazi istraživanja. Taj je problem jasno vidljiv i kod pitanja vezanih npr. Uz sindrome koji su se pokazali prilično problematičnima za osnovnu školu pogotovo kad je riječ o aberacijama spolnih kromosoma.

\section{METODIČKI ZNAČAJ}

Utvrđene miskoncepcije i problemi s razumijevanjem životnog ciklusa i oplodnje tijekom učenja biologije u osnovnoj školi ukazuje na potrebu promjene u poučavanju sa svrhom sprečavanja uočenih problema. Za razvoj konceptualnog razumijevanja bioloških sadržaja, nastava biologije trebala bi biti vođena izgradnjom koncepata što se lakše postiže upotrebom novijih nastavnih strategija $u$ usporedbi s tradicionalnom, predavačkom nastavom.

Tijekom nastave učenici često izrađuju modele staničnih dioba bez povezivanja tih procesa $\mathrm{s}$ odgovarajućim primjerima zbivanja u organizmu. Bilo bi dobro kad bi se dinamični modeli izrađivali na način da se u istom prikazu poveže nastanak spolnih stanica mejozom, oplodnja i nastanak zigote, te dalje mitoza tjelesnih stanica u svrhu rasta i razvitka organizma. Također bi bilo dobro tražiti učenike da te procese prikazuju crtežima, stripovima ili stop animacijom u kontekstu životnih ciklusa različitih organizama, stanica i tkiva. Općenito, u nastavi se životni ciklusi organizama uglavnom promatraju samo makroskopski, pa učenici teže povezuju naučene životne cikluse sa zbivanjima na razini stanice. Osim korištenja modela, interaktivne igre u kojima bi učenici mogli određivati tijek opisanih ciklusa te vidjeti kakvo bi značenje njihove pogreške imale za živu stanicu ili organizam, što bi bilo korisno pomagalo pri povezivanju nastavnih sadržaja i uspostavi uzročno-posljedičnih koraka, procesa i pojava. U nastavi se teže dolazi do otkrivanja nekih miskoncepcija, jer se rijetko od učenika traži da primjene svoje znanje u određenom kontekstu na dubljoj razini kao što na primjer da odrede u kojoj se fazi razvoja jedinke definiraju njeni geni, smatrajući da je svima jasno da geni ovise o kromosomima koje potomci nasljeđuju od roditelja. I ova se miskoncepcija može ukloniti izradom modela životnog ciklusa stanice, oplodnje i razvoja zametka iz zigote, posebno obraćajući pažnju na vrste i broj kromosoma koji u tim procesima sudjeluju. Aktivnost bi se mogla izvršiti tako da učenici modeliraju mutacije broja kromosoma, npr. Klinefelterov sindrom, Downov sindrom, itd. pazeći da grešku naprave namjerno u pravom dijelu životnog ciklusa stanice, te da pripaze da se tijekom dijeljenja zigote i razvoja u zametak stanice ne mijenjaju, već nastaju njihove identične kopije. 
Miskoncepcija uočena uz razlikovanje haploidnih i diploidnih stanica se u nastavi može ukloniti detaljnim proučavanjem i ilustriranjem nasljeđivanja i životnog ciklusa stanice. Sve uočene miskoncepcije mogu se izbjeći ako se pri poučavanju demonstriraju konceptualne mape uz detaljno objašnjenje poveznica i mogućnosti samostalne izrade konceptualne mape (Radanović i sur, 2017) u kojoj bi se moglo primijeniti znanje o životnim ciklusima i oplodnji u novim kontekstima.

\section{LITERATURA}

Adamov, J., Segedinac, M., Cvjetičanin, S., Bakos, R. (2009) Concept maps as diagnostic tools in assessing the acquisition and retention of knowledge in biochemistry. Odgojne znanosti, 1, 53-71.

Barker, M., Carr, M. 1989. Photosynthesis: can our pupils see the wood for the trees? Journal of Biological Education: 23, 1 , 41-44.

Begić, V., Bastić, M., Radanović, I. 2016. Utjecaj biološkog znanja učenika na rješavanje zadataka viših kognitivnih razina. Educ. biol., 2, 13-42.

Berthelsen, B. (1999). Students Naïve Conceptions in Life Science. MSTA Journal, 44(1) (Spring'99), pp. 13-19. http://wnw.mstamich.org

Braš Roth, M., Markočić Dekanić, A., Markuš Sandrić, M. 2017. PISA 2015., Prirodoslovne kompetencije za život. Zagreb: Nacionalni centar za vanjsko vrednovanje obrazovanja - PISA centar.

Din Yan Yip (1998) Children's misconceptions on reproduction and implications for teaching, Journal of Biological Education, $33: 1,21-26$

Garašić, D. 2012. Primjerenost biološkog obrazovanja tijekom osnovnog i gimnazijskog školovanja: doktorska disertacija Prirodoslovno-matematički fakultet Sveučilišta u Zagrebu. 348 str.

Garašić, D, Radanović, I., Lukša, Ž. 2013. Usvojenost makrokoncepata biologije tijekom učenja u osnovnoj školi i gimnaziji. Metodike u suvremenom odgojno-obrazovnom sustavu, Milanović, D., Bežen, A., Domović, V. (ur.). Akademija odgojno-obrazovnih znanosti Hrvatske, Zagreb, 211-239.

HBD 2017. Natjecanja učenika. http://mww.hbd-sbchr/natjecanja-ucenika/ preuzeto 29.5.2017.

Hopkins, W.G. 2000. A new view of statistics. Internet Society for Sport Science. http://www.sportsciorg/resource/stats/ preuzeto 15.09.2017.

Latin, K., Merdić, E., Labak, I. (2016) Usvojenost nastavnog sadržaja iz biologije primjenom konceptualnih mapa kod učenika srednje škole. Educ. biol., 2:1-9.

Lorenzo, M., Crouch, C.H., Mazur,E. 2006. Reducing the gender gap in the physics classroom. Am J Phys 74, 118-122, DOl: 10.1152/advan.00061.2005. preuzeto 1.4.2017.

Lugar, L., Mustać, A. 2016. Uspješnost učenika osmog razreda u rješavanju pisanih zadataka iz biologije. Educ. biol., 2, 49-66.

Lukša, Ž. 2011. Učeničko razumijevanje i usvojenost osnovnih koncepata u biologiji: doktorska disertacija. Prirodoslovnomatematički fakultet Sveučilišta u Zagrebu. 317. str.

Lukša, Ž., Radanović, I., Garašić, D. 2013. Konceptualni pristup poučavanju uz definiranje makrokonceptualnog okvira za biologiju, Život i škola, br. 30, 2, 156-171.

Lukša Ž., Radanović, I., Garašić, D. 2013. Očekivane i stvarne miskoncepcije učenika u biologiji. Napredak: časopis za pedagogijsku teoriju i praksu. 154, 4, 527-548.

Lukša, Ž., Radanović, I., Garašić, D., Sertić Perić, M. 2016. Misconceptions of Primary and High School Students Related to the Biological Concept of Human Reproduction, Cell Life Cycle and Molecular Basis of Heredity. Journal of Turkish Science Education (TUSED). 13,3, 143-160.

Michael, J. A., Wenderoth, M.P., Modell, H.I., Cliff, W., Horwitz, B., McHale, P., Richardson, D., Silverthorn, D., Williams, S., Whitescarver, S. 2002. Undergraduates' understanding of cardiovascular phenomena. Advanced Physiology Education 26, 72-84

Modell, H. I. 2000. How to help students understand physiology? Emphasize general models. Advances inPhysiology Education 23, 101-107.

Modell, H., Michael, J., Wenderoth, M.P. 2005. Helping the learner to learn: the role of uncovering misconceptions. The American. Biology Teacher 67, 20-26.

Momsen, J.L., Long, T.M., Wyse, S.A., Ebert-May, D. 2010. Just the Facts? Introductory Undergraduate Biology Courses Focus on Low-Level Cognitive SkillsCBE-Life Sciences Education. 9, 435-440.

MZOŠ 2006. Nastavni plan i program za osnovnu školu. Ministarstvo znanosti, obrazovanja i sporta Zagreb. Nakladnik Dragan Primorac, urednici Dijana Vican i Ivan Milanović Litre.

Novak, J. D., Cañas, A. J. 2008. The Theory Underlying Concept Maps and How to Construct and Use Them, Technical report IHMC CmapTools 2006-01 Rev 01-2008, Florida Institute for Human and Machine Cognition, 2008.

Radanović, I., Ćurković, N., Bastić, M., Leniček, S., Furlan, Z., Španović, P. \& Valjak, M. 2010. Kvalitativna analiza ispita provedenih 2008. godine u osnovnim školama, Izvješće o projektu - Biologija, Nacionalni centar za vanjsko vrednovanje, Zagreb.

Radanović, I., Bastić, M., Begić, V., Kapov, S., Sumpor, D., Mustać A.( 2013) Preporuke za autore i recenzente provjera natjecanja u znanju biologije. HBD. http://wnw.hbd-sbchr/wordpress/wp-content/uploads/2013/06/Preporuke-za-autoreirecenzentenatjecanja-20131.pdf. Preuzeto 31.7.2017. 
Radanović, I., Garašić, D., Lukša, Ž., Pongrac Štimac, Z., Bastić M., Kapov S., Karakaš D., Lugarić S., Vidović M. 2015. Ispitni katalog za Državnu maturu iz Biologije. NCVVO, Zagreb. 53 str.

Radanović I., Lukša Ž., Begić V., Bastić M., Gotlibović G., Kapov S., Pavunec S., Toljan M. 2017.a Sadržajna i metodološka analiza ispita državne mature iz Biologije školskih godina 2013./2014. i 2014./2015. NCVVO Zagreb, 101 str.

Radanović I., Lukša Ž., Pongrac Štimac Z., Garašić D., Bastić M., Kapov S., Kostanić L., Sertić Perić M., Toljan M. 2017.b Sadržajna i metodološka analiza ispita državne mature iz Biologije u školskoj godini 2015./2016. NCVVO Zagreb, 212 str.

Radanović,I., Lukša, Ž., Garašić, D., Sertić Perić, M., Gavric, B., Begić, V., Novoselic, D. 2017.c The effect of learning experiences using expert concept maps on understanding cell division processes..- ESERA (European Science Education Researche Association), Dublin. Ireland.

Ristić Dedić, Z., Jokić, B., Šabić, J. 2011. Analiza sadržaja i rezultata ispita državne mature iz biologije, NCVVO i IDIZ, Zagreb Ruiz-Primo, M., Schultz, S., Li, M., \& Shavelson, R. 2001. Comparison of the reliability and validity of scores from two concept-mapping techniques. Journal of Research in Science Teaching, 38, 260-278.

Tanner, K., Allen, D. 2005, Approaches to Biology Teaching and Learning: Understanding the Wrong Answers-Teaching toward Conceptual Change. Cell Biology Education, 4, 112-117.

Wood, W.B. 2009. Revising the AP biology curriculum. Science 325, 1627-1628. 